Portland State University

PDXScholar

$5-1-1968$

\title{
The library board and the conscientious objector : a study in war hysteria
}

Annette Martha Bartholomae

Portland State University

Follow this and additional works at: https://pdxscholar.library.pdx.edu/open_access_etds Let us know how access to this document benefits you.

\section{Recommended Citation}

Bartholomae, Annette Martha, "The library board and the conscientious objector : a study in war hysteria" (1968). Dissertations and Theses. Paper 254.

https://doi.org/10.15760/etd.254

This Thesis is brought to you for free and open access. It has been accepted for inclusion in Dissertations and Theses by an authorized administrator of PDXScholar. Please contact us if we can make this document more accessible: pdxscholar@pdx.edu. 
AN ABSTRACT OF THE THESIS OF.

ANN ETTE MARTHA BARTHOLOMAE FOR THE MASTER OF ARTS IN HISTORY

Date thesis is presented: May 14,1968

Title: THE LIBRARY BOARD AND THE CONSCIENTIOUS OBJECTOR: A STUDY IN WAR HYSTERIA

Abstract approved:

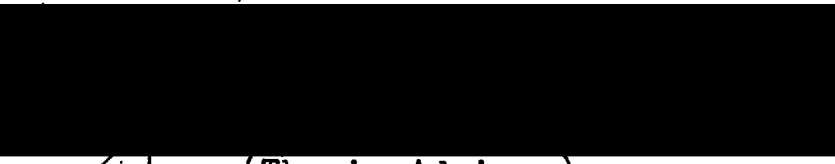

(U) (Thesis Adviser)

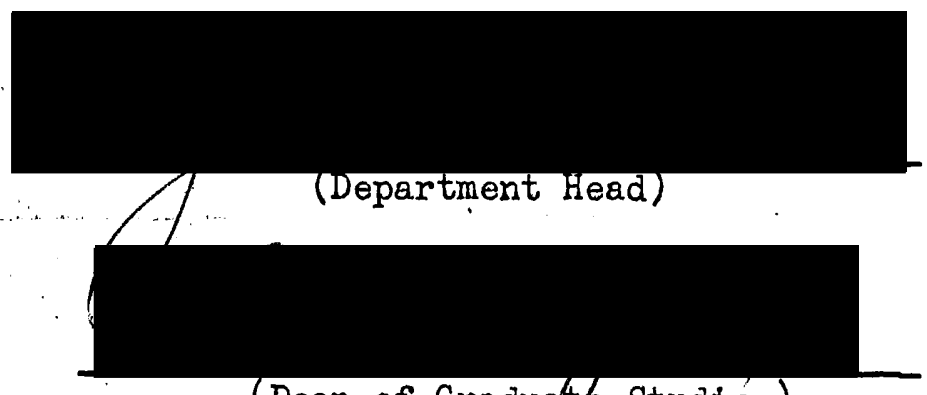

(Dean of Graduate Studies) 


\section{THESIS ABSTRACT}

The Selective Service Act of 1917 made provision for the exemption of conscientious objectors belonging to certain religious bodies. It did not provide protection for the sincere individual objector against vilification from a public who labeled him disloyal, unpatriotic, and pro-Hun.

This report is based on an incident which occurred in Portland, Oregon. It involves the assistant librarian of the Library Association of Portland who was a conscientious objector, and the repercussions which her stand had on the Iibrary board, the head librarian, and the public in general. ,

In April of 1918, Portland had just completed a successful drive for contributions to the third Liberty Loan drive. Indeed, Oregon was the first state to complete its quota. On the day that this victory was confirmed, an afternoon paper broke the news that the assistant librarian of the public library, Miss M. Louise Hunt, had refused to buy bonds. This action touched off a heated controversy which affected not only Miss Hunt herself, but involved the governing body of the library. Before, the incident was closed, civic and social organizations and individual citizens found an opportunity to express their views on the subject of conscientious objections. 
Miss Hunt refused to purchase bonds on the ground that she was a conscientious objector and could not support the war. Her opponents pointed out that she was a well paid county employee and therefore was under obligation to support the war bond drive.

A committee from the bond drive headquarters, calling on Miss Hunt at the library, tried to persuade her to change her mind. Her statements, as quoted in the press, were ill-chosen and branded her in the public mind as pro-German. She was also interviewed by an agent of the United States District Attorney.

Public indignation was so aroused that a special meeting of the . Ilbrary board was called to consider the matter. With one dissenting vote from the board itself and one from the chairman of the county commissioners who serve as ex-officio members of the library board, the board went on record as believing that Miss Hunt had never in any way obstructed, nor intended to obstruct, the activities of the Government. Although the board plainly stated that they did not share in any way Miss Hunt's opinions, they felt the right to one's own conscientious opinion was the very foundation of human freedom. They were unwilling to compel anyone to give up the very thing for which the war was being fought. This, in 1918, was a most unusual and courageous stand for any civic body to take in the face of accusations of disloyalty.

Public disapproval of the board's action was so great that a second meeting was held to reconsider the decision. At this time, Miss Hunt presented her resignation from the library staff. By now, tempers were frayed and the dissenting board member protested the board's stand. Charges 
of disloyalty were hurled against the president of the board and the head librarian. Immediately, civic and social groups demanded the dismissal of the governing body.

Wiser voices spoke up in defense of both board and librarian and the press turned from personal detalis of the squabbling to a more objective discussion of the principles involved in freedom of conscience. Miss Hunt returned to her home in Maine and, as far as Portland was concerned, the Hunt affair was over.

In a larger sense, the Hunt case forced Portland to confront, if only briefly, its historical ideals and to consider to what degree it was willing to protest the right to dissent during a period of crisis. 
THE LIBRARY BOARD AND THE CONSCIENTIOUS OBJECTOR: '

A. STUDY IN WAR HYSTERIA

$$
\text { by }
$$

ANNETTE M BARTHOLOMAE

\author{
A THESIS \\ Presented to the Department of History \\ and the Graduate Council of Portland State College \\ in partial fulfillment \\ of the requirements for the degree of \\ Master of Arts in History
}

May 1968 
APPROVED:
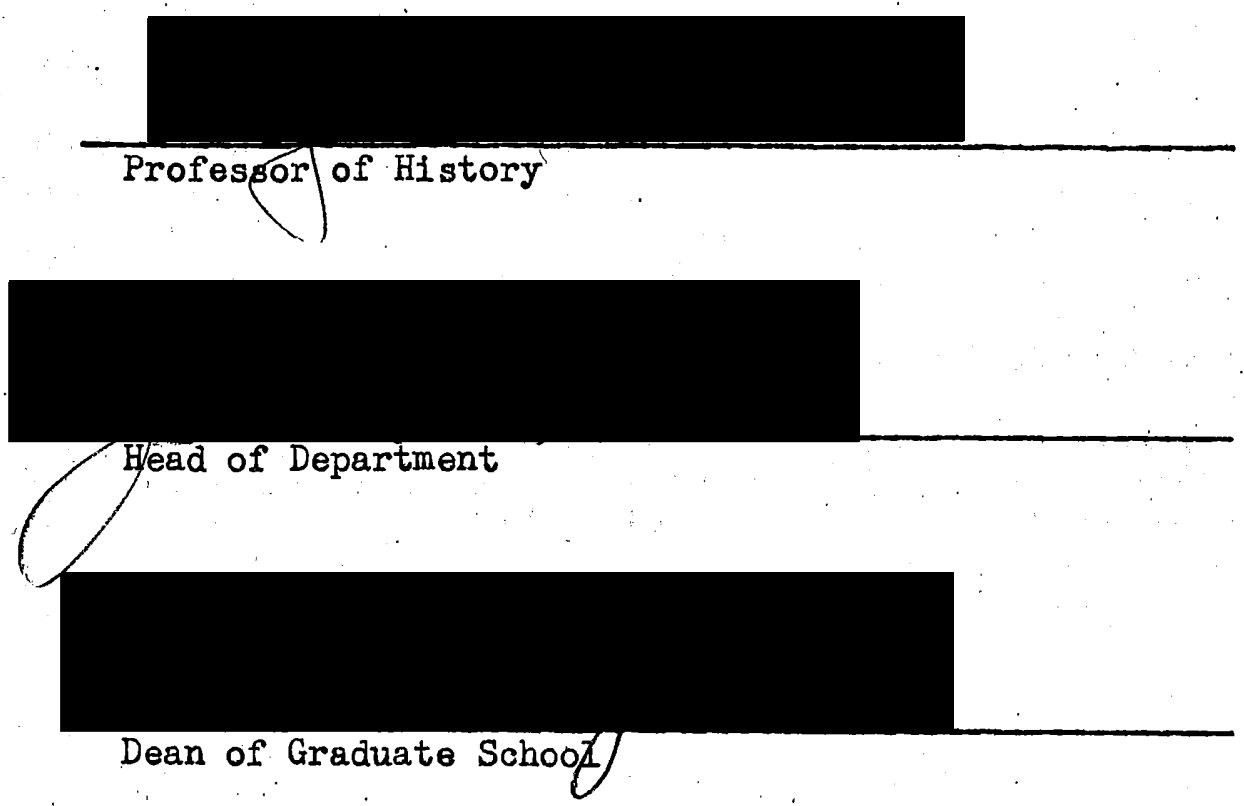

Date Thesis is presented May 14,1968 
TABLE OF CONTENTS

Page

INTRODUCTION ................... 1

Chapter

I. SPRING, 1918: THE TEMPER OF

THE TINE ............. 3

II. THE CONSCIENTIOUS OBJECTOR. AND THE

LIBERTY LOAN DRIVE ....... . . 13

III. THE CONSCIENTIOUS OBJECTOR AND THE

GENERAL PUBLIC . . . . . . . . 33

IV. THE ROLE OF THE LIBRARY BOARD . . . . 45

V. THE CASE OF THE CONSCIENTIOUS OBJECTOR

AFFECTS THE LIBRARY STAFF AND THE LIBRARIAN 54

EPILOGUE . . . . . . . . . . . . . . 58

BIBLIOGRAPHIC ESSAY ........... 61 


\section{INTRODUCTION}

In the spring of 1918 the state of Oregon, and the city of Portland in particular, was caught up in a fever of patriotic ferment generated by United States participation in the First World War. In this all-out effort to support President Wilson, "doing-your-bit" was a way of life for Portlanders. War gardens, daylight saving time, wheatless bread, and meatless days affected everyone. There were drives of every variety including those for paper and old clothes, Armenian and Syrian relief, and membership in the Red Cross and the Y.M.C.A. But no war activity produced quite the frenzied enthusiasm as did the third Iiberty Loan Drive, which opened on the anniversary of our entrance into the war and had a goal of three billion dollars. Portland prepared for this event by vacating. a street in the heart of the city and erecting a "Liberty Temple" to serve as headquarters for the drive. The planning was so well executed and the response so favorable that Oregon earned the distinction of being the first state in the country to reach its war bond goal.

Just as Portland, always the leader in such wartime actions, was taking justifiable pride in a task well done, an event occurred which clouded the gay victory celebration. On April 12, in headlines on the front page, the city learned that Miss M. Louise Hunt, the assistant Iibrarian of the Library Association of Portland, had refused to buy war bonds. Immediately the hue and cry was on. An indignant public demanded the resignation, not only of Miss Hunt, but of the Library Board and the head Iibrarian. Miss Hunt justified her refusal to purchase bonds by the argument generally employed by the conscientious objector--that she 
could not, with a clear conscience, support the President's war program. The unusual aspect of the Hunt case was the stand taken by the members of the Library Board. Seven members declared, with only one dissenting vote, that they would not try to coerce her, since she had a right to follow the dictates of her own conscience. This negative vote also represented the opinion of the county commissioners who were ex-officio members. The opposition expressed the point of view, shared by most Portland citizens, that any public employee had an obligation to support the country's war efforts. Although public opinion in such matters has altered over the years, in 1918 this defense was unacceptable. Before the witch-hunting was over, ministers, bankers, educators, ordinary citizens, and civic organizations had joined to condemn the beliefs of Miss Hunt and her defense by the Library Board. Portland's reaction in this case provides an interesting study in the type of war hysteria peculiar to the United States during the First World War.' 


\section{CHAPTER I I}

SPRING, 1918: THE TEMPER OF THE TIME

To put the Hunt case in its proper 'context, it is necessary to review briefly the state of the nation and of Oregon in the spring months of 1918. The war on the Western Front still seemed a long way from Oregon. The troops then in France were mainly regular army units and National Guard components from Eastern states. Of those in France, only a few had been called up to the front lines to serve in the British sector. Daily casualty lists were still a thing of the future. Such deaths as had occurred among the local men in uniform were, for the most part, due to the usual incident of disease or camp accidents. There had been a brief flurry of anxiety when the news came of the torpedoing of the Cunard Iiner, Tuscania, off the north coast of Ireland. 1 . She was carrying the 20th Engineers, a forestry regiment, made up in part of Northwesterners, but the casualties, remarkably few, included no Oregonians. Headlines and dispatches describing events in Russia and the seizure of power by the Bolshevik government seemed very remote.

What was going on along the home front was real and immediate, if not always understandable. The government had taken over the railroads and the coal mines, wheat was under government control, the cost of supporting the war was assuming astronomical proportions. The country had

\footnotetext{
1 The Morning Oregonian (Portland), February 8, 1918, p. 1.
} 
witnessed the enactment of the Selective Service Act of 1917, a euphemism for conscription. Anti-conscription agitation resulted in rallies which were broken up by police and ended in trial and imprisonment for the participants. Drives to round up slackers were made by police and federal officers in many of the larger cities. Such campaigns were carried out with more zeal than judgment; Senator Hiram Johnson declared that it was unbelievable that such things could happen in "free America."2

Oregon was spared the agitation found in large cities and particularly those with a large percentage of foreign born. In contrast, Oregon boasted the highest proportion of voluntary enlistment of any state-90.11 percent, as of April first, 1918-- leaving only 717 men to be chosen under the first selective draft, the smallest number as well as the smallest proportion of any state. ${ }^{3}$ In contrast to the protest and violence which the draft produced in other parts of the country, the Oregonian could report on April first, as the first draftees left for camp, "Multnomah County and Portland today sent to join the fighting forces of the United States the finest men they have been called on to contribute through draft or selective service procedure, 118 of the fittest recruits that could be sifted from the citizenry. 14

The Selective Service Act did make some provision for the conscientious objector; military exemptions could be given, provided the person claiming it belonged to a religious body which opposed war. Thus, those

\footnotetext{
2H. C. Peterson and Gilbert C. Fite, Opponents of War, 1917-1918, (Madison: University of Wisconsin Press, 1957), p. 233. $20,1918)$, p. 7 .

3"Oregon's Patriotic Record," Oregon Voter, XIII, No. 3, (April 4The Morning Oregonian (Portland), April 1, 1918, p. 1.
} 
who asked for exemption because of religious principles, particularly if they belonged to such recognized anti-war groups as the Mennonites or Quakers, had relatively little trouble with their draft boards. However, the act did not exempt all objectors. Besides the religious objector there was the socialist who felt that the country had been needlessly and erroneously involved in war. There was also the third type, the individual who denfed the right of the government to force the citizen either to fight or to do anything contrary to his own conscience; hence, he became a nonconformist at a time when the state claimed absolute authority over the citizen. 5

Criticism from ordinary citizens was effectively silenced by the wartime laws against espionage and sedition (passed June 15, 1917 and amended May 16, 1918) which prescribed penalties for speaking, printing, or otherwise expressing contempt for the government or the Constitution, or the flag, or the unfform of the Army or Navy, and saying or doing anything likely to restrict the sale of war bonds. Under the provisions of this act, objectors to the operation of the Selective Service Act were suppressed. It also served as a deterrent to criticism of the American economic system as all leftists were accused of being disloyal. These dissenters included Socialists and, most particularly, members of the I.W.W. While Socialists were often respected citizens, I.W.W. became Identified in the public mind with sabotage, pro-Germanism, and disloyalty.

5The position of the "dissenter" is vividly described in Peterson and Fite (op. cit.). 
In many parts of the country, aliens and Negroes also came under attack as undesirables. 6 .

Criticism was acceptable if it was super-patriotic. Oregonians read, with uneasy admiration, the speeches of their senator, George Chamberlain, who accused the administration of inefficiency in its support of the Army. This Democrat found a strange bedfellow in Theodore Roosevelt who shared honors with the Senator at a luncheon given by the National Security League. Roosevelt proclaimed "Back Mr. Chamberlain; back Mr. Kahn [Julius Kahn7], in seeing that every hindrance of having these men supported by this nation is taken away. 8 Senator Chamberlain was, after all, Chairman of the Senate Committee on Military Affairs, a position which gave him a particular right to speak out in criticism.

Not only was the dissident voice suppressed by law; it was also drowned out by the sheer volume of sound coming from a completely new kind of agency for the United States, the Committee on Public Information. Although President Wilson officially initiated it, the agency became in effect the creation of its chairman, George Creel. An author and a newspaper man of considerable experience, Creel developed a news bureau and a set of syndicated services which gave the administrative slant to events and explained away false or damaging rumors. Speakers' bureaus supplied speakers for the liberty loan drives. Seventy-five thousand orators were groomed for the famous "four-minute talks" at churches, movies, civic is given in John Dos Passo's, Mr. Wilson's War, (Garden City: Doubleday and Company, 1962), p. 219, passim.

7 Julius Kahn was a member of Congress from California from 18991903 and 1905-1919. He led in securing the passage of the Selective Service Act.

${ }^{8}$ The Morning Oregonian (Portland), January 20, 1918, p. 2. 
centers, and even street corners. In a short time the whole nation, minus a small minority that insisted on forming its own opinion, followed completely the Iine of opinion coming from the President's desk. Dissent was not tolerated. "Once lead this people into war," Woodrow Wilson told Frank Cobb of the World, "and they.'ll forget there ever was such a thing as tolerance." 9

Intolerance found its way to Oregon where even the college campus was not immune. The Oregonian reported that disloyalty was not to be tolerated at the "U." The University of Oregon Board of Regents at Eugene, according to the paper, adopted a resolution expressing in emphatic terms the attitude of the University concerning disloyal expressions of opinion or acts on the part of any member of the faculty. The president of the University was directed to report immediately to the Board the name of any instructor accused in writing by a responsible citizen of being in any manner disloyal. 10

And at Grants Pass, in the southern part of the state, when Pastor W. A. Baker of the International Bible Student's Association of Brooklyn, New York, arrived for a speaking engagement, the meeting was cancelled. City officials called Reverend Baker into their chambers and asked him,

"Are you whole-heartedly and unreservedly backing the Government war plan?" His reply was "No." He attempted to open debate but he was told that no debate would be tolerated and he was asked to leave the room. "The whole interview;" boasted

9 This quotation was used in every book consulted, The only complete citation is given in Peterson and Fite, (op. cit.), p. II. The authenticity of the Cobb-Wilson exchange is challenged in Jerald S. Auerbach, 'Woodrow Wilson's'Prediction' to Frank Cobb: Words Historians Should Doubt Ever Got Spoken," The Journal of American History, IIV (December, 1967), pp. 608-617.

10 The Morning Oregonian, (Portland), February 17, 1918, p. 10. 
the reporter, "lasted not more than three minutes, but it was long enough to show the resolute determination of the men who comprise the Council of Defense to prevent, any attempt at holding meetings of this sort in Grants Pass."11

Portland had one problem not shared by the rest of the state. Because of the wartime shipyard activity along the willamette and because Portland was an important railhead, there were mumors of sabotage

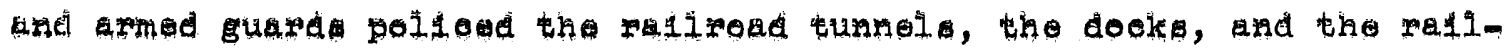
road stations. Nevertheless, the average Portlander was more concerned with the everyday details of wartime living than with spy and sabotage scares. With "Hooverizing" came the various types of wheatless bread to experiment with: "Victory Bread" and "Camouflaged Bread." Tuesdays were meatless. Mayor George L. Baker urged all citizens to plant victory gardens. "Idle grourds," said the Mayor, "will not be tolerated."12 And the drives! Money was contributed for Armenian relief, old clothes were collected for war refugees, memberships were sold for various patriotic organizations. But above all there were the Liberty Loan drives. That Oregon, spear-headed always by Portland, had an enviable record is attested to by these figures compiled by the Oregon Voter:

\section{OREGON'S PATRIOTIC RECORD}

First Liberty Loan--Oversubscribed 31\%-Quota, \$9,000,000; 15,715 subcriptions, $\$ 11,802,900$.

Second Liberty Loan-Minimum Quota Oversubscribed $40 \%-$ Minimum quota, $\$ 18,000,000$; maximum quota, $\$ 30,000,000$; 57,314 subscriptions, $\$ 25,248,600 ; 24$ of 36 counties exceeded minimum quotas; three counties, Benton, Union and Wallowa, exceeded maximum quotas.

11 The Morning Oregonian, (Portland), February 25, 1918, p. 1. 12The Morning Oregonian, (Portland), March 4, 1918, p. 1 . 
Third Liberty Loan--Oregon First State in Union to go over the top in making its quota. Every banking city in Oregon, except one, made its quota.

First Y.H.C.A. War Fund--Oversubscribed 22\%-Quota, $\$ 30,000$; subscribed, $\$ 36,766.33$.

Food Conservation--22\% of families signed pledge cards, 135,764 of 148,251 families.

Food Product10n--46\% Increase of Winter wheat acreage.

Second Y.M.C.A. War Fund--Oversubscribed 33\%-Quota, $\$ 300,000$; subscribed, $\$ 398,993.84$.

First Red Cross War Fund--Oversubscribed 73\%--Quota, $\$ 600,000$; subscribed $\$ 1,038,653.36$.

Red Cross Membership Drive-Minimum Quota Oversubscribed 140\%-Quota, minimum 100,000 members; maximum, 240,000 members;

obtained, 240,683; highest proportion to population of any state.

Knights of Columbus War Fund--Oversubscribed 29\%-Quota, $\$ 75,000$; subscribed, $\$ 97,000$.

Armenian and Syrian Relief Fund--Subscribed 100\%-Quota, $\$ 150,000$; subscribed, $\$ 150,000$; drive not completed in all counties.

War Camp Community Fund--Subscribed 100\%--Quota, $\$ 25,000$; subscribed, $\$ 24,930$.

Y.W.C.A. War Fund--Portland Oversubscribed 6\%--Quota, $\$ 50,000$; subscribed $\$ 43,383.55$; reports from several counties lacking; Portland oversubscribed $\$ 25,000$, quota $6 \%$.

War Library Fund--Oversubscribed 150\%-Quota, $\$ 8,000$; subscribed $\$ 19,965.18$; highest proportion of any state.

Boy Scouts--Subscribed 100\%-quota, $\$ 25,000$ a year for three years; subscribed in full, to exact amount.

Selvation Army War Fund--Oversubscribed 28\%--Quota, Portland only 25,000 ; subscribed, $\$ 32,000$; state drive not undertaken yet. 13

The climax of activity in the late winter of 1918 was the third Liberty Loan Drive. Late in February a noon "sing," held at Alder and

13"Oregon's Patriotic Record," Oregon Voter, XIII, No. 3, (April 20, 1918), p. 7. 
Sixth, opposite the Meier and Frank Department Store, had proved a great success. Thousands joined in the patriotic music festival which was held, as the Oregonian notes, "Under the folds of immense American flags which waved in the winter breezes. From the voices of the great throng came. forth the notes of the lovely sound 'America" swelling through the chill air for many blocks."14 This turnout impressed Julius Meier, the department store magnate, and other leading citizens. They proposed that a building be erected in the downtown area to serve as a civic center for similar patriotic rallies: Early in March the plans were drawn up for the erection of the Liberty Temple. The City of Portland vacated Sixth Street between Yamhill and Morrison, providing the necessary ground. A group of prominent citizens donated the necessary funds and organized labor supplied the construction crews for the building which the newspapers likened to a stately Grecian temple. Portlanders liked to claim that this Liberty Temple, "the finest symbol of Portland's war democracy that the city has ever: produced," was built in a day. 15 In fact, the framework for the building, flanked on the east by the post office and on the west by the Portland Hotel, was erected in twenty-four hours, but the plastering and finishing took several weeks. Although similar temples were built in other parts of the state and nation, Portlanders maintained that their structure was the first of its kind in the country.

When the temple was dedicated on Tuesday, March 19, the main address was delivered by Rabbi Jonah B. Wise of Temple Beth Israel. The Washington High School Band, led by Professor W: H. Boyer, accompanied the crowd

14The Morning Oregonian, (Portland), February 23, 1918, p. 14. . 15 The Morning Oregonian, (Portland), March 11, 1918, p. I. 
in singing "Keep the Home Fires Burning" and "Over There."16 This, however, was but a preliminary to the big kick-off to open the third Liberty Loan campaign. Portland's aim, as announced by "General" Guy Talbot, head of the drive, was to be the first city in the United States to subscribe her quota. 17

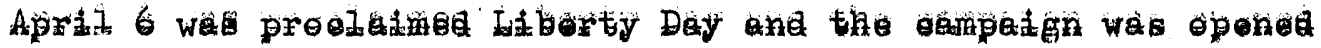
by a gigantic parade which featured contingents from Camp Lewis and Fort Vancouver as well as floats representing various war industries. Eight bands, including military, high school, and fraternal, provided the martial music. ${ }^{18}$ Prominently displayed on the pages of the local papers was this statement addressed "To workers in All Lines of Industries."

In order to facilitate the taking of subscriptions for the third liberty loan Saturday next, April 6th, and continuing until the entire quota for Portland is absorbed, we have been requested by the employers of this city to ask your loyal cooperation and support in this great cause of democracy and freedom, and that you immediately proceed to take up with your employer a definite plan of organization, so that each and every one of you will be prepared to hand to the captain and his team, which will visit your organization in the near future, the actual amount that you will loan the Government in this third liberty bond issue.

This notice was signed by Talbot, Julius Meier and James A. Cranston. ${ }^{19}$

The local chairman, Edward Cookingham, reminded Portlanders that: "'Over the top in a week' is the slogan. Liberty loan subscribers should

${ }^{16}$ The Morning Oregonian, (Portland), March 20, 1918; p. 4. William Herr Boyer was supervisor of music for the Portland Public Schools.

${ }^{17}$ Guy W. Talbot, President of the Pacific Power and Light Company and Portland Gas and Coke.

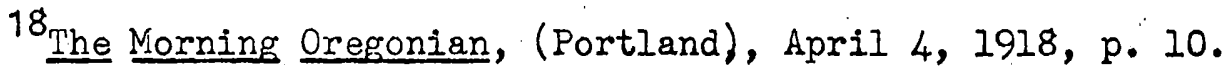

${ }^{19}$ The Morning Oregonian, (Portland), April 3, 1918, p. 13: 
be ready. Have your answer and your initial deposit, which will be 5 per cent of the amount that you are willing to invest in bonds, ready for one of the 2,000 solicitors who will come to the city."

Even the clergy participated actively in the drive, since pacifism was not supported by most religious groups in 1918. "Fight or buy bonds" was the titie of an address given by a Methodist minister before the Portland Rotary Club. "There is no place,'said he, 'on the top side of American soil for a Pacifist. . . There is no room in this country for a Pacifist. If you have one, shoot him. Don't talk peace to me; I don't want peace, I want righteousness.' "1."

Careful planning on the part of the drive officials and the enthusiastic response of the citizens paid off. As the early returns began to come in, it became apparent that Oregon and Portland might indeed lead the nation in subscribing their quota, which was set at $\$ 50,000,000$. Of this amount, $\$ 25,000,000$ was to be raised in Portland. The Evening Telegram, which appeared on the street on April 12, carried the news that Oregon had won national honors for being first to subscribe its quota. Next to this front page announcement, and in banner headlines, the city learned that "Librarian With Big Pay Check Will Not Purchase 22 . Bonds."

20

Ibid.

21

The Morning Oregonian, (Portland), April 10, 1918, p.7. The role played by the clergy in supporting the war is reviewed by Peterson and Fite (op.Cit.), p. 113, passim.

22

Portland Evening Telegram, April 12, 1918, p.1. 


\section{CHAPTER II}

THE CONSCIENTICUS OBJECTOR AND THE LIBERTY BOND DRIVE

It would be hard to find a more unlikely candidate than Miss M. Louise Hunt for so much publicity and notoriety. A New Englander born in Portland, Maine, in 1876, she had joined the staff of the Library Association of Portland in 1910. Miss Hunt was a graduate of the Drexel Library School and had served as Iibrarian of the Lansing, Michigan,. Public Library before coming to Portland. Her original appointment. was to substitute for Miss E. Ruth Rockwood, the reference librarian, who had been granted a leave of absence. Miss Hunt was soon to become the assistant librarian, working directly under Miss Miary Frances Isom. Miss Isom, one of the truly great librarians of this country, belonged to. what is sometimes referred to in library circles as the Era of the Crowned Heads.. Setting a high standard of excellence, she had a temper often roused by sloth, mediocrity, or selfseeking. She was not a patient woman. Her staff members admired and were proud of her to an inordinate degree. They worked desperately to do what she wanted because she inspired them. ${ }^{1}$ Miss Isom would not have tolerated anyone less than excellent for her next in comand. The Library Association's annual report for the year ending in October, 1917, notes that Miss Hunt had been granted a leave of absence to do special work at Columbia University.

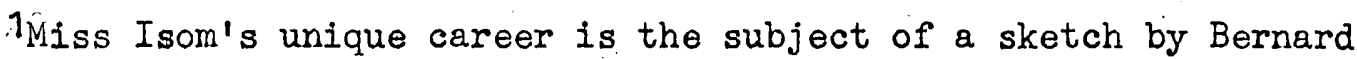
Van Horne, "Mary Frances Isom: Creative Pioneer in Library Work in the Northwest," Wilson Library Bulletin, XXXIII (February, 1959), pp. 409-416. Mr. Van Horne is a former librarian of the Library Association of Portland. 
On April 4, 1917, Washington Dispatches told that:

A Miss Hunt of Portland, called on the Congressional delegation from this state, demanding that they vote against the war resolution then before Congress. At that time nothing further about the identity of Miss Hunt was known but yesterday it was learned from reliable sources that this was Miss M. Loulse Hunt, who has now refused to support any patriotic activity.

According to advices from Washington at that time, Miss Hunt received a cold reception from all but one of the Oregon delegation,

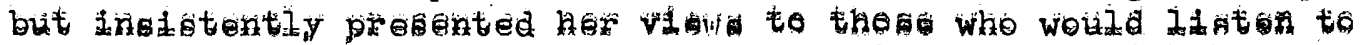
them. Representative Hawley told her he "disagreed with her sentiments as to Germany." Senator Chamberlain informed her he was in hearty accord with the President.2

The Oregonian might have reminded its readers that in April of 1917, many Americans were opposed to war. Miss Hunt was only one of thousands who sprang into action with the breaking off of diplomatic relations between Germany and the United States. With this action,

Emergency Peace Federations appeared everywhere. Their members tried to influence Congress and the press, and police chased some of them from the steps of the Capitol. Petitions against war flooded Congress. The Seattle Union-Record of April 7, 1917, stated that labor organizations in Seattle, Spokane, and Chicago opposed a declaration of war. On the same day, the Sacramento Bee reported that most of the mail addressed to California congressmen was against war. President Wilson, it was said, received thousands of telegrams reminding him he had been elected to keep the country out of war. 3

But a year later the legitimacy of such protestations had been forgotten.

There is no evidence to prove that Miss Hunt was an active member of any peace organization. No voice from any such group seems to have been raised in her defense. Her stand was in every way a very personal thing. Miss Isom must have discussed with Miss Hunt the possible reper-

2Morning Oregonian (Portland), April 15, 1918, p. 1.

3 Peterson and Fite, op. cit., p. 3. 
cussions, should news of her refusal to participate in the bond drive be made public. Perhaps they both hoped that her attitude would not attract attention. However, the news leaked out through an anonymous letter. According to the Oregonian, "It is understood the original charge against her was made through the medium of an anonymous letter. This brought her to the notice of the Governiment officlals and to the workers for the third liberty Ioan." 4

The Telegram, coming out in the afternoon of Friday, April 12, was the first Portland paper, and the only one on that date, to carry the story of the Hunt incident. The paper made the most of this scoop, giving it banner headlines. 5 According to the Telegram, the facts on the Hunt case came to light on Thursday, April 11, when G. M. Locke, of Lang and Co., and. C. I. Wilson, of Hartman and Thompson, were detailed by the Liberty Loan executives to call on Miss Hunt to find out why she had failed to subscribe to any of the three bond issues. According to their sworn statement, Mr. Lang and Mr. Wilson called on Miss Hunt, the Assistant Librarian, at the Central Library. Before contacting Miss Hunt, the gentlemen met with Miss Isom, the head librarian, explained the purpose of their call, and asked her if she could give them the information they were seeking or if she would prefer that they contact Miss Hunt directly. Miss Isom informed the gentlemen that she had exhausted all her arguments with Miss Hunt; that she was most unhappy with Miss Hunt's failure to subscribe; and that she would' prefer them to talk to her directly. She then took the two bond workers to Miss Hunt's office and introduced them.

4The Morning Oregonian (Portland), April 13, 1918, p. 8.

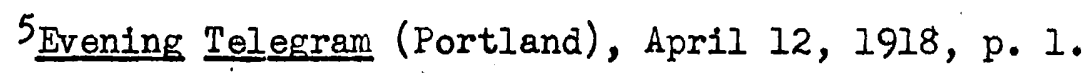


Miss Hunt explained to her callers that she had not subscribed to the first and second bond drives because she had been away on sick leave, traveling for her health. She added that she wouldn't have subscribed anyway, and had no intention of supporting the third drive since she did not believe in war.

She was then asked if she were a citizen of the United States, to which she replied that she was, and that she came from Portland, Maine. Did she not, suggested her interrogators, think that it was the duty of every citizen to support the United States; to buy as many bonds as possible; and thus help the government to keep our army in France since they were there for her protection? Miss Hunt replied that she didn't feel she had to put patriotism above her personal feelings. Moreover, she had seen her attorney, Mr. Richard Montague, and he had advised her that she did not have to subscribe unless she so desired.

When Miss Hunt suggested that she was being coerced into buying a bond, she was assured that there was absolutely no thought of coercion. The gentlemen were there, she was assured, only to point out to her, with all the force they could muster, that it was her duty to support the government, regardless of whatever her personal belief might be. Indeed, the government was not trying to take money from her but rather asking her to " loan the money at a favorable interest rate. To which Miss Hunt replied that it might be a good business proposition to loan the government money at $41 \% 2$ per cent and probably a good many people were doing just that as a business proposition rather than from any patriotic feelings, but she wasn't subscribing under any circumstance.

Miss Hunt: was then asked if she realized that the cruelties the Huns were practicing in France and Belgium included the ravishing of 
women. The boys now fighting in France were there, she was reminded, to protect her from the same fate. Miss Hunt replied that she was prepared for any suffering. If the government wanted her money, it could come and get it, but she would never make a loan voluntarily.

At the conclusion of this interview, the bond workers hurried back to headquarters in Iiberty Temple and turned in a full report on their interview. The matter was considered serious enough to be reported immediately by the bond drive officials to United States District Attorney Bert Haney who ordered Special Agent William Bryan to arrange for an interview with Miss Hunt. What exactly happened at this interview is not too clear since it was conducted in privacy. Miss Hunt was accompanied by her attorney, Richard Montague, a member of the Library Board. According to the Telegram, "Just what transpired has not been made public but it is said the library employee denied she welcomed attack by the Huns rather than invest in a Liberty bond." 6

Whatever else she may or may not have said in the presence of $\mathrm{Mr}$. Bryan, Miss Hunt certainly reiterated her position in opposition to war and her refusal to purchase bonds. United States District Attorney Haney made the following statement to the press regarding Miss Hunt's attitude:

You can quote me as saying enphatically that no person with such unloyal and unpatriotic tendencies as the woman in question should be permitted to hold a public office, irrespective of whether he is strictly within his legal rights or not. There can be no persecution as there is no law to force any citizen to purchase Liberty bonds but there is a moral oblightion higher than any law of man that might or could be enacted.?

6Ibid., April 12, 1918, p. 2.

7. Ibid. 
Federal Food Administrator W.B. Ayer, president of the board of directors of the library association of Portland, said this morning that he would call a special meeting of the board as soon as possible to consider the charge against Miss Hunt.

"I spoke to Miss Isom, Iibrarian, yesterday about the matter," said Mr. Ayer, "and she told me that at no time had she heard of Miss Hunt giving utterance to any disloyal or unpatriotic sentiments. The woman is highly efficient and this is the first complaint we have had about her."

Rabbi Jonah B. Wise, a member of the library board, when interviewed at the Liberty $\mathrm{T}$ emple, stated that he preferred not to give out a statement since he believed that any comment on the case should come from the investigating committee. 9

Mr. Locke and Mr. Wilson, the investigators from the bond committee, were quoted as saying that they regretted the publicity which the matter had attracted but Mr. Locke added, "It was our patriotic duty to make a full report of the matter and as loyal Americans we could take no other action: "10

The News of the Hunt case was of particular interest and concern to Portland's financiers. At a well-attended meeting held at one of the city's financial institutions on Friday morning, April 12, those present expressed their indignation over Miss Hunt's action. It was their unanimous opinion that steps should be taken at once to remove Miss Hunt from her position. "If the library officials refuse to take action," one banker was. reported to have said; "I am in favor of taking legislative or other action to deprive the institution of any financial support by the tax payers."II

\footnotetext{
${ }^{8}$ Ibid,

9 Ibide

10

Ibid.

11

Ibid,
} 
Mr. Ayer, as president of the board of the Library Association of Portland, called a special board meeting for Friday evening, April 12, at eight o'clock to consider the charges of disloyalty against Miss Hunt, the Assistant Librarian. Mr. Ayer presided at the meeting and the following board members were present: R. W. Montague, R. L. Sabin, Elliott R. Corbett, W. M. Ladd, R. H. Strong, W. L. Brewster, W. F. Woodward, and Dr. Jonah B. Wise. Of the three county commissioners (ex-officio members of the library board), only Rufus C. Holman, Chairman of the County Commissioners, attended. 12

There was a delay in opening the meeting and Mr. Holman left before - any action could be taken. He asked that a statement be incorporated into the minutes. As a county commissioner, he said, he assumed the position of speaking for Multnomah County and he asked to go on record as opposing the continuance in employment by the Government of anyone who refused to support the Government.

After the Board had discussed the case thoroughly, Miss Hunt was summoned into the room. She answered the various questions which were put to her by the different members of the Board and submitted to them the following statement:

Some of the statements that appeared in an evening paper of April 12 are true, but they are so stated that the general impression given of my opinions and attitude are incorrect.

I do not wish to discuss the article in detail; but simply to state that $I$ am and always have been intensely and wholeheartedly concerned for the best interests of the United States.

This is my country. I was born here. My ancestors were born here for many generations back. Both sides of my family fought in the Revolution and also in the Civil War. I am an American, and no one can more earnestly desire to see America leading in the world's progress to a higher civilization. It

${ }^{12}$ Library Association of Portland. Minutes of the Meeting, April 12, 1918. The Board minutes are bound chronologically and kept in the Library Board room. 
is increasingly a source of pride to me that in this conflict our President now stands head and shoulders above the statesmen of the other warring nations.

His aims and ideals and those of other earnest people with whom I disagree are my aims and ideals. The disagreement is purely an honest difference of opinion about the methods which will best achieve those ends.

At no time have I desired to be an "obstructionist," I merely wish to claim the constitutional American right privately to hold a minority opinion.

Upon her withdrawal a vote was taken and the following resolution

was passed, Mr. Woodward alone dissenting:

RESOLVED, in the matter of charges publicly made against Miss M. Louise Hunt, Assistant Librarian, the Board at meeting called for that purpose has had read newspaper article and affidavit of the solicitors of the Liberty Loan Committee upon which the same is based, and has taken Miss Hunt's statement and examined her orally concerning the same, and is now of opinion that the newspaper article and the affidavit do not correctly represent the facts, and finds that there is no cause for further action on the part of the Board in the premises. RESOLVED further, that the president appoint a committee to make written statement of the views of the Board as expressed at the meeting.

It was then voted that a committee be appointed by the president to prepare a statement of the views of the Board for the press. Mr. Brewster, Dr. Wise, and Mr. Sabin were appointed to this committee. The following statement was then prepared by the committee:

The Board has carefully considered the charges brought against Miss $M$. Louise Hunt through the press and by affidavit. After such consideration and a thorough examination of Miss Hunt as to her position in the premises, the Board finds that Miss Hunt is not chargeable with any overt act of opposition of criticism of the policy of our Government.

Miss Hunt is a faithful and valuable public servant. She is in opinion opposed to all war at all times. Most members of the Board have long been cognizant of these views; they have not been publicly expressed. The expressions complained of were elicited from her in a manner which did not permit her to state them with clearness. They were given in answe to questions and not volunteered. These statements were so construed and published as to give them a meaning not intended by Niiss Hunt. 
Her conduct has never in any way obstructed, or tended to obstruct, the activities of our Government. She is, in principle, opposed to any such obstruction or to any encouragement or incitement to obstruction in others.

Her duties in carrying out the war savings stamps campaign in the Library have been conscientiously and efficiently performed. None of the Board shares in any degree her opinions. However, the Board feels that the right to one's own conscientious opinion is the very foundation of human freedom, and we are not willing to give up, or to compel others to give up, in advance the very thing for which the best and bravest of us are now fighting, and which our ancestors risked their lives to win for us.

The Oregonian for Saturday, April 13, carried headlines on page one stating "Miss Hunt cleared by Board."14 This report was substantially a repetition of the action outlined in the board minutes as well as a summary of the action taken by Mr. Locke and Mr. Wilson of the Liberty Loan Committee and by United States District Attorney Haney.

The Evening Telegram for that day carried an editorial labeled "The Case of Miss Hunt."15 Judging from the sworn statement of the two reputable men who questioned her, the editorial pointed out, Miss Hunt. typified the extreme of pacifism. Although nothing in her statement showed her to be an active pro-German, it nevertheless carried the implication that she was not opposed to the Kaiser's domination of the world. This, the Telegram felt, made Miss Hunt most offensively un-American.

The fact that Miss Hunt was in public service, the paper pointed out, put her case on at least a semi-public basis and as such it should be treated. And although no federal or state statute covered the case, public opinion could be relied on to condemn and punish her.
${ }^{13}$ Ibid.
14 Morning Oregonian (Portland), April 13, 1918, p. 1. ${ }^{15}$ Evening Telegram (Portland), April 13, 1918, p. 4. 
She has acted contemptibly toward her country and banished herself from friendly association with loyal Americans. When she seeks residence somewhere away from Portland, her record will follow her. She may find corpanionship among Germans, but not now, except under false pretense, among Americans who love their native land.

After these harsh words, the paper added that Miss Hunt was a woman of intelligence and her ability to fill her position at the library was proof of her education. She should, therefore, have known the difference between democracy and autocracy, between vassalage and freedori, civilization and savagery, between our benign government and malign imperialism, between popular right and military might, between conservation of Iife and wholesale human butchery, between God and the devil. And yet, the editorial pointed out, with all this knowledge Miss Hunt refused to lift a finger for the preservation of political liberty and for the destruction of the greatest menace to peace and happiness in the world. The editorial ended with these lines:

In the heart of every normal man, woman and child there dwells love of country. This love inspires them, when their country is in danger, to defend it even with their lives. We call the expression of this love patriotism. What patriotism is in normal Americans is in Miss Hunt a perfect vacuum. Doubtless, Louise Hunt is familiar with Edward Everett Hale's immortal story, "The Man Without a Country." She is a woman without a country by her own volition. 16

The Journal's headlines read "Vote in Miss Hunt's Case Protested. Library Board's Action Sustaining Stand on War Rouses Storm."17 Leaders of the Liberty Loan drive, according to the paper, met at Il:30 A. M.

${ }^{16}$ Ibid.

${ }^{17}$ Oregon Daily Journal (Portland), April 13, 1918, p. 1... 
to consider what course of action should be taken to counteract the effect of the incident. Chairman Emery Olmstead named a committee to ask the directors of the Library AsBociation to reconsider their action. "In case the association directors refuse to do as requested, other means of clearing up the situation will be taken," Mr. Olmstead was quoted as say18

ing. The committee was to make its report at 3 P.M.

Mr. Woodward, the dissenting member of the Library Board, gave a lengthy interview to the Journal, explaining in some detail his stend 19 on the issue. He had, he stated, bitterly opposed the exoneration of Miss Hunt at the board meeting held Friday night. He felt that a serious mistake had been made both by Miss Hunt in refusing to get behind the Government in the war crisis and by the board members in sustaining her. Mr. Woodward emphasized that as far as he was concerned, the incident was by no means closed.

It was his contention that no public employee drawing $\$ 175$ a month (or any other substantial sum) who refused to support his country in time of war should be retained in public service.

It was Mr. Woodward's belief that the incident would not be closed until the German army was driven out of France and the Kaiser put underground. Miss Hunt, he felt, had made it quite apparent by her calm and collected manner at the meeting, that her mind was made up and that she had no intention of changing it.

Mr. Woodward stated that he had asked Mr. Ayer the following question:

18

Ibid.

${ }^{19}$ Ibid. 
How do you reconcile your attitude with the action of the government in enforcing food regulations upon the people? If it is morally right for a person.to refuse to support the government war program by declining Liberty bonds, it is morally right for a dealer in flour to refuse to abide by the government's Iimitations on the ground that he is a conscientious objector. 20

Rufus Holman, the only county commissioner who attended the evening meeting, and who left before the vote exonerating Niss Hunt was taken, repeated to the press his views on the affair. "Being the only county commissioner who answered the call of the president of the Library Board for this special meeting, I will assume to speak for the county. I object to the continuance in employment in the service of the government. anyone who refuses to support the government. I desire to be recorded accordingly on this question in the minutes of the meeting." 21

Mr. Ayer explaining his view of the incident said,

In sustaining the position taken by Miss Hunt we undertook to perpetuate the spirit of individual freedom of thought which activated the founders of this government. We found nothing wrong with Miss Hunt's attitude toward the government so far as any overt act was concerned. She is a pacifist and is conscientiously opposed to war. She is not an obstructionist and has done nothing or said nothing so far as I have been able to learn which would tend in any way to obstruct the government's war program. She has not attempted to convince others to follow her dictates and has not tried to speak her doctrine of opposition to war.

We found nothing in the record of Miss Hunt's stewardship at the library which would reflect discredit upon her. She is a capable and earnest worker. 22

If $\mathrm{Mr}$. Ayer and the Library Board were satisfied, an irate public refused to consider the incident closed. The Sunday papers on April 14

20

Ibid.

21

Ibid.

22 Ibid. 
again carried front page headlines. "Discharge of Miss Hunt is demanded," declared the Oregonian. "Anti-war Iibrarian has raised a tempest. Board's action condemned. Indignation is general. Action of Library attendant insult to motherhood, says Mayor. Liberty loan workers fully aroused."23 Following these headlines the paper gave a capsule summary of Saturday's action which included an 1I:30 A.M. indignation moeting staged at Liberty Temple at which a resolution was adcpted asking that the Library Board reconsider its action and a second meeting at the same place at 2:00 P.M. at which time the committee had expected to make its report. However, more time was asked. Finally, at 5:00 P.M., the committee was able to report that a second meeting of the board of directors of the Library Association would be called on Monday night to decide whether the matter should be reconsidered.

There was no doubt in Mayor George L. Baker's mind regarding the Hunt case. The Mayor gave the paper the following statement:

Miss Hunt's attitude is an insult to the motherhood of our nation and to their boys who are knee-deep in the muddy trenches of France fighting for liberty. Nothing short of her dismissal fron an institution where our boys and girls are compelled to go and must of necessity come in contact with a mind that is wholly un-American and un-sympathetic to our common and vital cause will suffice in this case.

The Library Board must act, and quickly, too, so as to clear the stain from the name of our otherwise thoroughly loyal state. 24

A committee from the Liberty loan headquarters called on Mr. Ayer to present a petition asking for a reconsideration of the board's action.

${ }^{23}$ Sunday Oregonian (Portland), April 14, 1918, p. 1. ${ }^{24}$ Ibid. 
Mr. Ayer announced that "I will send copies of the resolution to the other directors and advise them of the called meeting. 25 (He said further than this he would not be quoted.) The meeting was set for Monday evening.

Mr. Ayer was pressured into this move by actions which the Oregonian described as:

Early yesterday the stow of protest broke about the of the library board of directors. Telephones poured angry remonstrances into Liberty Temple and the newspaper offices. They learned early in the day of the tremendous wave of unpopularity they had rolled up by their action of Friday night. Miss Hunt herself sought safety in seclusion yesterday. She left the city for the weekend and it was not known where she was. It was announced, however, that she will return to Portland tomorrow. 26

General Guy W. Talbot, of the third Liberty Loan drive, was quoted as saying that the library officials "Have taken an academic position as to the liberty of conscience, whereas, today, with the cause of the allies hanging in the balance, an active militant patriotism is the need of the hour. $" 27$

The Oregonian commented that the position of the library directors was known to be: "that all struggles from the earliest time to the present are useless, unless liberty of conscience is given. They hold that the cauldron of molten. lead should not bubble, nor the pot of oil be set aboiling to persecute one who holds rigidly to one's own faith since conscience, not public opinion, is the real mentor." 28 This comment would have seemed more appropriate on an editorial page than in a news report.

$$
\begin{aligned}
& 25 \text { Ibid. } \\
& 26_{\text {Ibid. }} \\
& { }^{27} \text { Ibid. } \\
& { }^{28} \text { Ibid. }
\end{aligned}
$$


The Sunday Journal reported that a number of local civic organizations, including the East. Side Business Men's Club and the Portland Ad Club, were planning to adopt resolutions of condemnation. The City Federation of Women's organizations, representing some 50 to 60 of the women's clubs of the city, passed a unanimous resolution at its regular meeting on Saturday, addressed to the library board, protesting its action. 29

The local papers took special care to point out that Miss Hunt had been in charge of the War Stamp station at the Central Library; her duties included purchase and re-selling of Thrift Stamps and War Savings stamps. Jesse Currey, state distributor of the War Stamps, sent a letter to W. L. Brewster, chairman of the social and library committee of the organization, expressing the demand of C. S. Jackson, State Director, that Miss Hunt no longer be identified with the War Savings Stamp organization in any way whatsoever. Campaigners working on the bond drive, reported the Journal, complained that people were declining to purchase bonds on the grounds that they, too, were conscientious objectors. 30

A set of resolutions, adopted by the bond workers, and signed by A. C. Spencer, H. L. Corbett, J. C. English, C. D. Brunn, and Fred L. Bourne, stated that now was not the time for individual opinion. Mr. Spencer pointed out that although it was true that no person's thoughts are controllable, any word or action which might be construed as tending to obstruct the government's war program would be subject to investigation by a grand jury. Since voluntary subscriptions, he continued, must be resorted

\footnotetext{
${ }^{29}$ Sunday Journal (Portland), April 14, 1918, p. 4. 30 Ibid.
} 
to in order to obtain the necessary sinews of war, anyone who would spread the propaganda that the government should finance the war by taxing the wealthy would be obstructing the government's program. 31 If Mr. Spencer was referring to a statement of Miss Hunt's on taxing the rich, the reference is not clear.

Tho Sunday Journel carried an editorial titled "Miss Hunt's Caso" which referred to the library board statement that "the right to one's own conscientious opinion is the very foundation of human freedom." 32 Miss Hunt's stand was based on the constitutional right privately to hold a minority opinion. How, the Journal asked, had the Library Board and. Miss Hunt earned the right to such opinions but by war, the very kind of war so odious to Miss Hunt? "The doctrine the library board so soundly enunciates and that Miss Hunt so stoutly maintains, is blood bought. It was established by those whose bloody footprints were left in the snow at Valley Forge."

As the board knows and Miss Hunt ought to know, continued the editorial, this principle is now hanging in the balance and must stand or fall by war. It would seem then that Miss Hunt is not on sound ground when she refused to buy bonds to aid a war being fought to preserve her constitutional American right to hold a minority opinion.

The editorial wound up its case with the statement that "It is the approved custom, sanctioned by long and honorable precedent for those holding public position, whenever they cease to be in harmony with the government, to resign." 33

\section{Ibid,}

32 Sunday Journal (Portland), April 14, 1918, p. 8. ${ }^{33}$ Ibid. 
The meeting which had been urged on the board of directors of the library by the bond drive committee, by individuals, and by public pressure in general, was held at noon on Monday, April 15. Attending with the regular members of the board were the three ex-officio county commissioners, Philo Holbrook, A. A. Muck, and the chairman, Rufus Holman. The Liberty loan committee was represented by C. D. Brunn and J. C. English, Reporters from the three city newspapers were also present. 34

It was a truly dramatic meeting. The board room, which in 1918 was located on the second floor of the Central building, was one of great beauty and dignity with its high ceilings and walls panelled in rich, dark wood. The massive table and chairs, also in dark wood, might have graced the executive rooms of a Wall Street banking firm. The high window gave the room a subdued light.

Nir. Ayer presided and as the first and main piece of business to be transacted, called for the reading of the resignation of Miss Hunt. Mr. Woodward insisted that the minutes of the previous meeting be read first. He then asked that the minutes be amplified to include the statement that "Miss Hunt, on questions propounded, stated that she was not a member of the Red Cross and had not and would not aid the Red Cross and she had not and would not subscribe for Liberty bonds; that she did not believe in this war or any war, and would not support it." 35 .

In order that the motion might be brought up for discussion Mr. Ladd seconded it. However, the motion was lost, Mr. Holman and $\mathrm{Mr}_{\mathrm{r}}$. Woodward voting in the affirmative.

${ }^{34}$ Library Association of Portland. Minutes of the Board Meeting; April 15, 1918.

\section{Ibid.}


The secretary then read the formal resignation of Miss Hunt:

To the Directors of the Library

Association of Portland, Oregon

Gentlemen:

Because $I$ do not wish in any degree to hamper the usefulness of the Library, and because I am unwilling to place upon the Library Board the burden of a conflict to maintain its brave stand for freedom of conscience, I herebyr tender my resignation as Assistant Librarian, to take effect at once.

Nir. Woodward moved, seconded by Mr. Holman, that Miss Hunt's resignation be laid on the table and that she be dismissed from her position and that the position be declared vacant. Mr. Woodward and the three county commissioners voted in the affirmative but the motion lost.

Mr. Ladd moved, seconded by Mr. Sabin, that Miss Hunt's resignation be accepted, Mr. Holman and Mr. Woodward voting no.

The board minutes show that $\mathrm{Mr}$. Woodward then asked the secretary if, at the previous meeting, she had not signified her admiration for the action of the Library Board and had said that she intended to resign if such action had not been taken. Miss Isom assured him that she did Indeed stand by the Board and that she had not changed her mind. On being questioned by Mr. Brewster, Mr. Woodward stated that he doubted the librarian's loyalty. This statement, according to the minutes, was resented by the librarian.

Mr. Ayer, as presiding officer, said:

Mr. Woodward, in accusing Miss Isom of disloyalty is insulting to her and to the Board of which he is a member. Miss Isom's loyalty is too unquestioned and has been one in too many ways to be questioned. She has contributed to practically every war activity and in her handling of the War Library Campaign has secured recognition for the Portland Library as leading the United States in war activities, due to her intense and active patriotism. 

I do not hesitate to condern in most forceful language
Mr. Woodward's statements and his action as being reprehensible. 36

On this note the meeting adjourned.

However, the dispute between Mr. Woodward and Mr. Ayer continued, much to the delight of the reporters who gave the exchange full coverage.

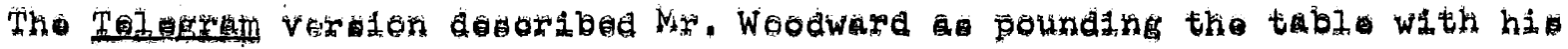
fist, his eyes snapping and rather pale faced, when asked if he questioned Miss Isom's loyalty. "Pandemonium then broke loose with the majority of the board all trying to talk at once." $37 \mathrm{~N}$ iss Isom was described as angered beyond all restraint, leaning across the table to call Mr. Woodward something which sounded like "You are no gentleman!"38

Mr. Ayer was reported as saying "In my opinion Mr. Woodward has acted in a disloyal manner to this board and his action is unwarranted and most distasteful." He added "I trust the press will give all prominence to my remarks." According to the Telegram, his remarks included this statement: "I want to be quoted as saying that Mr. Woodward's conduct is yellow and he is yellow clear through." 39

Other members of the board, reported the Telegram, indulged in much vitriclic comment and as a result of the affair the storm which had centered about Miss Hunt had paled into insignificance.

"Miss Hunt," the Journal reported on April 15, "has not been at the

36 Ibid.

37 Evening Telegram (Portland), April 15, 1918, p. 1.

${ }^{38}$ Ibid.

${ }^{39}$ Ibid. 
library since she handed in her resignation Sunday. With her resignation she sent a worran friend to the library to gather up a few personal belongings." 40 Miss Hunt slipped quietly out of Portland and returned to her home in Portland, Maine.

${ }^{40}$ Oregon Daily Journal (Portland), April 15, 1918, p. 15. 


\section{CHAPTER III}

THE CONSCIENTIOUS OBJECTOR AND THE GENERAL PUBLIC

The public that forced Miss Hunt's resignation had not been given the satisfaction it demanded. She had neither been dismissed from office nor officially censored by the library board. Public attention turned to a more general discussion of the issues involved.

Mr. Woodward, now a public hero and spokesman for the patriotic citizen, told the Oregonian on Monday, April 15, that he felt his position to be right and in justification referred to the sheaf of letters and telephone calls backing his demand for 100 per cent Americanism from all employees in public office. "The matter now lies with the public and with the Nation," he said. "The question is a principal [sic] and deals with all persons drawing public money. It goes beyond any individual. I am lost in it; so is Miss Hunt and Miss Isom and the other members of the library board." I

Mr. Woodward concluded his rather emotional declaration:

The people seem to realize that the hour has come when a new concept of duty to the Nation has been developed. It is absolute. There is no reason for argument over these questions. There is no chance to quibble at all.

It is a hard game, being in a fight of this kind, but I hope that out of it may come a clearer conception of what is the duty of every citizen of the nation.

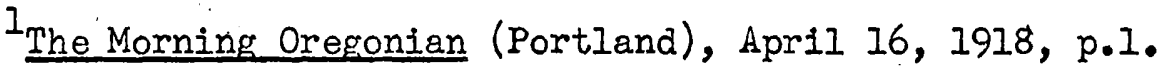


On Wednesday morning, April 17, the Oregonian editorialized that "It is as plain as a church steeple on ä prairie that the people of Portland are of one mind upon the subject of the controversies arising from the recent public library incident. This is attested to by a flood of communications bearing upon the attitude of Miss Hunt toward the liberty loan."2

The editorial went on to say that letters from the public have been too numerous to print but cites as an example one from "a prominent citizen who prefers to be known only as "Anti-Pacifist." Anti-Pacifist holds up for public approbation the case of a working girl, receiving a modest salary, who bought a bond and is working hard to purchase another. This attitude is contrasted with that of the well-paid library assistant who will do nothing while "the Kaiser, the monumental brute of all the ages, is permitted to violate all the decencies of civilization and go on indefinitely in his mad career of rapine and slaughter." This unnamed correspondent concludes by observing that "It is nonsense to pretend that the Pacifist is not an obstructionist. Academic freedom has always been the favorite battle cry for treason." 3

The Telegram printed a sheaf of letters on the editorial page for April 17. One signed "M. W." is addressed to Food Administrator Ayer and proposes a question. Suppose, suggests the writer, a conscientious objector, opposed to war in any way, had put aside five barrels of white flour. Being a conscientious objector, he would refuse to sell, lend, or give any of the flour to the boys fighting in France. How would Mr. Ayer treat that situation? In the case of Miss Hunt, suggests this writer, the

2 Ibid., April 17, 1918, p. 10.

3 Ibid. 
law did not fequire her to buy bonds, but money is quite as important as bread. What would Mr. Ayer do with a person who had flour but would not lend it because he conscientiously objected to war? 4

On the same page "Subscriber" commented on "a certain woman" whose plain-spoken Pro-Hun feelings have caused such strong resentment among

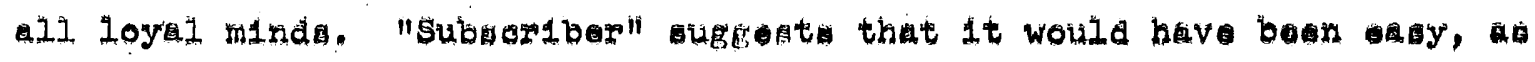
a matter of prestige and effect for this woman to have purchased her bonds and held her job. The trustees, he feels, should have been trying to help the war and not looking forward to future laurels. As soon as she had refused to purchase the first bond, she should have been "politely told to look to the Pro-Huns for her future salary." 5

"M. M. C." asked that the Telegram stand firm regarding Miss Hunt. If she were a patriotic woman. "whose heart scorns the atrocities enacted by the diabolical German horde of officers and soldiers," she could not withhold needed aid. Who; asks "M. M. C.", is Miss Hunt that she sets herself up as an authority--that her decisions are right and all Christendom wrong? The Portland incident, concludes this writer, is a disgrace to patriotic American womanhood. 6

On the same page with these letters appeared an editorial, "Disloyalists, Beware!" For the first time since the country had gone to war, the editorial noted, Portland has given expression to her views of the conscientious objector. "In Portland's lexicon, 'conscientious objector' is

4 The Evening Telegram (Portland), April 17, 1918, p. 10.

5 Ibid.

6 Ibid. 
defined as 'disloyal,' which is the equivalent of 'traitor.' The mild word 'slacker' to designate those who do not do their full duty, has fallen into disuse." 7

This editorial is of particular interest because it reports a speech made in Portland on Saturday, April 13, by President Henry Suzzalo of the University of Washington. President Suzzalo is quoted as saying "Some marvel that the American people who have always detested militarism, particularly that phase of it known as conscription, should under the stress of national peril have so heartily supported the draft law. We are soon to take the next step," continued Mr. Suzzalo:

We have long since recognized the law that he who eats must work--that he who shares in material benefits must help produce them. Soon we are going to insist that he who shares in other benefits, the non-material ones, which our free government provides, must contribute actively to the maintainence of that government in whatever way the occasion demands. He may not remain passive. He may not plead conscientious objections to the object sought or to the kind of support required of him. The conscienticus objector must go the way of the loafer and the anti-conscriptionists. 8 .

The Telegram went on to comment that the events of the past few days. in Portland had caused people to take the next step and demand removal of the conscientious objector from public office.

The few disloyalists in Portland may, if they choose, continue to think pacifism in pre-war terms, but they dare not think aloud. They must put a padlock on their lips. The people of Portland are not in a mood to listen to anyone who by word or deed, by act of omission or comission fails or neglects to support his government.'

\section{Ibid. \\ 8 Ibid. \\ 9. Ibid.}


The editorial goes on to remind its readers that "Oregon boys, the very flower of our youth - are fighting for us. Our own Portland boys, as dear to us as our lives, are fighting and bleeding and perhaps dying." No one who will not assist in the fullest measure at such times as these, adds the editorial, should be allowed to live in Portland and enjoy the protec-

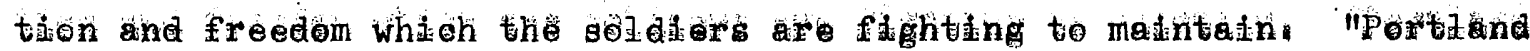
has given her answer. He that is not with the government is against it, and he will be dealt with accordingly. Let all disloyalists bewarel"10 If, during all the castigation and epithet-flinging, President Ayer remained stlent, one angry board member spoke out. In the Journal for April 17, Mr. Montague commented on the difficulty of getting a hearing on the rights of the Hunt case in the present inflamed state of public opinion.

When the war situation has become sufficiently improved that we can discuss in an urprejudiced.mind those who disagree with us, or enough worse that we may give up the 'Iuxury' of hating our fellow citizens for the grim and instant duty of fighting the Germans, I am sure that those who have so fiercely attacked Miss Hunt and led the public into a veritable hysteria will be ashamed of it all. I know some of them well enough to belleve they will now, if they will only look the facts squarely in the face and apply to them those essential principles of Anglo-Saxon liberty, which made the whole difference between this country and Prussia. 11

Mr. Montague then reviewed the various stages of the Hunt affair, adding that President. Ayer had called on him as chairman of the library comittee having to do with employees to represent Miss Hunt. Referring to the action of the Liberty bond committee, Mr. Montague stated that "it may be remarked that the performance of this committee was probably the worst exhibition of the art of salesmanship of which there is any record." 12

10

Ibid.

11 Daily Journal (Portland), April 17, 1918, p. 3.

12 Ibid. 
The report they tendered, Mr. Montague suggested, was inexact and distorted. Yet, he added, it was only on the strength of this report that the hue and cry for Miss Hunt's discharge was based. Because of it, the Liberty loan headquarters seethed with fierce indignation and the Mayor fulminated in "Bakeresque" bathos.

Mr. Montague defended the action of the library board, sinoe aftior careful examination it found no cause for further action against Miss Hunt. Mr. Montague did not find the distinction between public and private obligation to purchase bonds tenable. The hint that Miss Hunt should be interned, he pointed out, would result in her being provided for at public expense. "It has not yet been officially suggested that she should not be allowed to live at all. The anonymous letter writers who are diligently supporting the campaign in their own pleasant way have the monopoly of that suggestion to date." 13

Back of this Mr. Montague saw a graver, deeper, and more terrible question - whether the people of Portland and the United States were willing to yield to the rising tide of hate against all who disagreed with them or whether they should oppose it:

To the last barrier which liberty has erected and maintained here for 100 years and say that, though we must take (as I hold we. rightfully may) the lives and all the possessions of ourselves and our countrymen for the common cause, we will leave their souls free, that we are great enough not to hate those who cannot see the truth, the most sacred truth, as we see it, nor do them harm if only they hold their hands from wrong, but to teach them by brave and patient tolerance, by acceptance of all they can or will do for the cause, that we are right enough and sure enough of right to be patient, and as a friend, whom may heaven reward, wrote me today, "Leave it to the Huns to fight women and children." 14<smiles>[13CH3][13CH][13CH3]</smiles> 
This eloquent plea was made by one of the finest legal minds in the state of Oregon. Perhaps lawyers would evaluate more clearly than could the average citizen, the basis issues involved in this case. Another member of the legal profession, J. Hunt Hendrickson, a lawyer who would later serve as Oregon District Court Judge, spoke out on the subject of loyalty. In a letter to the Oregonian written on the afternoon of the second board meeting, Mr. Hendrickson commented on the fact that the board would be asked to judge whether a public employee would be compelled to purchase bonds or forfeit her position. "It is easy under pressure," he suggested, "to loose our poise and also the vision of that for which we are now fighting."15

Mr. Hendrickson reminded his readers that every great conflict brings with it a period of mob rule and cautioned Portland that only a matter of degree separated the action of the Illinois mob which strung up a man for refusing to kiss the flag and that of a committee which said buy bonds or loose your position. He placed the names of William Lloyd Garrison and Henry -Ward Beecher on his list of brave men who have contributed to the creation and preservation of complete liberty in this country.

He commented that he had never understood the prevalent opinion which holds that a public official is necessarily a legitimate target for mudslinging or why a library employee should be distinguished from a firm which sells heat or books to the library, if that firm has failed to subscribe its quota. Although he did not agree with Miss Hunt's viewpoint, Mr. Hendrickson asked his readers to adopt some other method than coercion to make clear to those who hold back, the fact that while all war may be undesirable, this war, as far as we were concerned, was absolutely necessary. The letter ended

\section{5}

The Morning Oregonian (Portland), April 15, 1918, p.6. 
with this appeal, "Let us not degenerate to the conception that might is right." 16

One rather odd letter, published by the Telegram, was signed Patrick o'Halloran. 17 It seemed to him that the majority of people who purchased bonds were activated far more strongly by a conscientious motive than by fear or by any desire to profit. Yet these same people were now conscientiously criticising Miss Hunt for obeying the same mandate they obeyed--the mandate of conscience. Mr. O'Halloran advised wide study in the various fields of knowledge as a basis for improving the conscience and giving it power to judge with greater ability. "The critics of Miss Hunt," he concluded, "may be well-meaning people enough, but less unintelligent or harsh criticism and more deep thinking should be their aim and also their duty." 18

The press eventually decided that the furor over the Hunt case had run its course. Everything of importance had been said; the reiterations were becoming pointless. Mr. Woodward and Mr. Ayer had exchanged apologies, Mr. Woodward, according to the Telegram, said very impressively that above all things Portland needed unity. Therefore, the paper suggested that it is the duty of the public to forget that either of these able, loyal citizens spoke an unkind word. "Everything has been forgiven. Let it be forgotten. $" 19$

The Oregonian echoed the same sentiment in an editorial "The calm after the storm." 20 The paper remarked that many things had been said

\section{Ibid.}

17 A Patrick O'Halloran was listed in the current Portland City Directory as a cement worker. Polk's City Directory (Portland), 1918.

${ }^{18}$ The Evening Telegram (Portland), April 17, 1918, p. 6. ${ }^{19}$ The Evening Telegram (Portland), April 20, 1918, p. 4. 20 The Morning Oregonian (Portland), April 20, 1918, p. 10. 
which ought not to have been said. The outbreak of public opinion had been a remarkable manifestation of the intensity of general feeling over the war, but it was not a reasoning sentiment. Rather, it was the instinctive expression of moral and spiritual reaction to the stress of the war. Nothing should prevail against the overpowering thought that patriotic duty now had but a single test; and it was service to the country in its time of need. The Journal suggested in "The Barbed Bayonet" that before we charge disloyalty we should be very sure of our ground. A breath of suspicion, once started, warns the editorial, is difficult to stop. Although the Journal did not agree with the action taken by the majority of the library board, it did not believe that any of their actions should be described as unloyal. "Among our own neighbors and longtime citizens we should all be sparing in the use of this glittering, poisoned, barbed bayonet word 'disloyal. 1121

With Miss Hunt's resignation, the Library Association of Portland closed its records on the case. The incident exists officially only in the minutes of the two special board meetings. There is no mention of the affair either in the monthly report of the librarian for April or in the annual report for the year.

The Hunt case ceased to be newsworthy and was soon forgotten by a fickle public. One point should be made. Miss Hunt was not the only person to run up against public disfavor. The Journal for April 13 reported that a William E. Robertson, President of Robertson Hardware and Steel Company, had been reported as a slacker by the solicitors for the Liberty loan drive. 22

21 The Daily Journal (Portland), April 18, 1918, p.10.

22 Ibid., April 13, 1918, p. I. 
Mr. Robertson, reported the paper, was listed for a subscription of $\$ 25,000$ by the rating committee, but he refused to buy the bonds. He gave as his reason the statement that the proposition did not appeal to him as a good business investment and he refused to consider it in any other light. He was reported as not having subscribed to any other drive. The paper reminded its readers that the steel business had been one of the chief beneficiaries of the war. Either Mr. Robertson had a change of heart, or, as the Journal reported on April 18, Mr. Robertson is an odd man in approach and $h_{a} s$ a peculiar way of attending to his own affairs." On more close investigation, the paper reported, Mr. Robertson was found to own $\$ 20,000$ in government short term certificates and had purchased in his wife's name $\$ 5,000$ in third Liberty Ioan bonds.

A Portland teacher did not fare as well as Mr. Robertson. Miss Nell. Moran, according to the Journal, was the only teacher in the city schools who declined to swear allegiance in obedience to a request of the School Board. She maintained that she was a. conscientious objector, opposed to war. School authorities were on record as being in favor of dismissal of anyone in public employment who was not 100 per cent patriotic. Miss Moran, as a consequence, was dismissed from her job.

The Hunt case neither solved nor resolved the problem of the conscientious objector in Portland. The arguments for and against were those that had been raised in other wars--they would be used again in later years. Some aroused citizens would see in Miss Hunt a real threat to national security, deeming her actions to be pro-German and therefore dangerous. Dismissal frcm her position would have seemed to them a very mild punish-

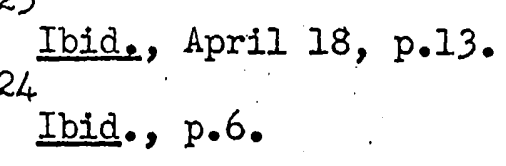


ment to be exacted from a disloyal citizen. Other members of the public, while not viewing Miss Hunt as a threat to security, would argue, and with reason, that a public employee does have an obligation to support such drives as those of the Red Cross and the war bonds in times of national peril.

The argument that such privileges as freedom of speech and liberty of opinion are earned and paid for by each generation also hás a logical basis. If the spirit of Valley Forge was evoked, it could be argued that each succeeding generation must also be willing to sacrifice its lives, future, and sacred honor for the same principles. The payment cannot be made once and for all time to come. Most Portlanders who sincerely believed that support of the country in time of danger was the obligation of every citizen in a free country would not have denied the general principle that every man has the right to his own belief. What they were arguing was that there is a moral obligation to country that overrides the right of a citizen to choose not to support his country when called upon to do so.

In contrast to this point of view was the classic position, taken by the library board, that one man's right to follow the dictates of his own conscience was the very basis of freedom and that in defense of this right Valley Forges have been endured. It is interesting to note that Miss Hunt's support, beyond the basic vote of confidence extended by the library board, came from lawyers. Both Mr. Montague and Mr. Hunt, however, made it plain that in their defense of Miss Hunt they did not support her point of view. but were defending her right to hold an unpopular opinion.

From the point of view of the librarian, the library staff, and the library board, one might question whether Miss Hunt was entitled by her choice of action to jeopardize their public image. Was one woman's insistence on her right to object worth the disturbance it stirred up? Should 
Niss Hunt have resigned before being forced to do so? Finally, was she a martyr or just a stubborn woman?

If the Hunt case did not add anything new to these often debated points of view, it did force Portland, if only for a brief moment, to consider whether the state can demand complete obedience or whether there is a higher authority within himself to which each man must answer. 
Like its successor today, the library board in 1918 occupled a unique position among Portland's governing bodies. The original Library Association of Portland, founded in 1864, was a subscription library. By the turn of the century, support for the private library was insufficient for proper maintainance. The magnificent gift of the private library of John Wilson, a Portland merchant, had been made to the Association with the stipulation that it be accessible to the public. The Board of Directors, realizing that Portland was ready for a public library, negotiated first with the City of Portland to combine the assets of the Association with public support. This basis was not broad enough and Multnomah County was finally established as the governmental body with which the old Association merged. But in so doing, certain perogatives were reserved to the library, the most important stipulation being that the library board was to remain self-perpetuating and non-political, with the County Commissioners acting in an ex-officio capacity. The librarian has traditionally acted as secretary to the board. This separation from direct political control has been the great strength of this body. ${ }^{1}$

${ }^{1}$ Katherine Eva Anderson, Historical Sketch of the Library Association of Portland, Portland, 1964. Written for the library's centennial, this gives a good description of the history of the library board. 
The lawyers, bankers, merchants, and, occasionally, clergymen, who have comprised the library boards over the years had always been chosen from among Portland's most distinquished citizens, and the library board of 1918 was no exception.

Serving as President of that Iibrary board was WInslow B. Ayer, a native of Bengor, Maine and President of the Eatern-Western Lumber Company. Few men have given as many devoted years to a civic organization as did Mr. Ayer to the Library Association of Portland. He served on the board from 1896 to 1921 and was president of the body from 1908 to 1921. His personal automobile, a White Steamer, and his chauffeur provided the first bookmobile for Multnomah County. In his will he left a large share of his estate to the library to be used as a retirement fund, a reflection of his concern over low salaries and lack of security in old age for the library staff. Besides the Iibrary, Mr. Ayer was active in the Portland Art Museum and the Oregon State Library. He served as War Food Coordinator for Oregon during the war years.

The Board included one clergyman, Dr. Jonah Bondi Wise, Rabbi of Congregation Beth Israel. Rabbi Wise, who left Portland in 1921 to become head of the Central Synagogue in New York City, was one of the foremost exponents of reform Judaism. He was a fighter for social welfare and an exponent of interfaith activities. Although he succeeded Rabbi Stephen Wise at Temple Beth Israel, the two were not related.

One of the prominent lawyers on the board in 1918 was William L. Brewster, who served from 1901 to 1937. Besides being a member of both the New York and Oregon Bars, he. belonged to many civic organizations and was one of the founders of the Oregon Historical Society. Serving with Mr. Brewster was Richard W. Montague, a member of the board from 
1908 to 1935 and Vice-President from 1914 to 1935. A president of the Oregon Bar Association and recipient of an honorary degree from the University of Oregon, Mr. Montague was a prominent Democrat and had been active in support of Woodrow Wilson during the Oregon primamry campaign of 1912. During the war, Mr. Montague was examiner for the Shipbuilding Labor Adjustment Board for the Portland District.

Several board members.were identified with Portland's financial institutions. The venerable William Mead Ladd served on the board from 1879 to 1893 and again from 1889 to 1926. Associated with the Ladd and Tilton Bank, he was a prominent layman in the First Presbyterian Church, .. active in the Y.M.C.A., and one of the builders, in 1889, of Cloud Cap Inn on the slopes of Mt. Hood. Robert H. Strong, who served on the Ilbrary board from 1909 to 1937, was prominent in Portland financial affairs. In 1918 he was the manager of the H.W. Corbett estate. Elliot R. Corbett, associated with the First National Bank, was a board member from 1911 to 1918. Robert I. Sabin, a board member from 1907 to 1921, served as VicePresident from 1908 to 1921. Mr. Sabin was also a member of the Portland School. Board and the Multnomah County Tax Supervising and Conservation Commission. In 1918 he was the Secretary of the Merchant's Protective Association of Portland.

Representing the merchants was William F. Woodward, Secretary-Treasurer of the retail drug firm of Woodward and Clarke. He was active in the Unitarian Church and in the Boy's and Girl's Aid Society.

Acting as ex-officio members of the library board were the three County Commissioners, Alvin Muck, Philo Holbrook, and Rufus C. Holman. Traditionally, the commissioners have not attended board meetings, being 
content to let the regular members formulate library policies. Mr. Holman was the only county official to take an active part in the Hunt incident. He was Chairman of the Board of County Commissioners and no doubt felt it his responsibility. Mr. Holman was President of Davis and Holman, bookbinders. He took an active part in many civic organizations and served as United States Senator for Oregon, 1938-1945.

Most of these gentlemen were members of such local prestige clubs as the Arlington and University clubs and the Waverley Golf Club. And by their memberships in civic, church, and private groups, they knew, and were known by, almost everyone of prominence in the city. It must have been a bitter blow to find themselves the object of newspaper castigation as well as criticism from the public at large, from civic and social groups, and from their friends and colleagues. After a gap of fifty years, we can only guess at some of the reasons behind their stand. Did the lawyers recall the provisions of the First amendment and the history of this country's fight for liberty of conscience? Mr. Montague acted as Miss Hunt's attorney in her confrontation with the delegates from the District Attorney's office. Was this help volunteered or only' a part of his duty as a board member?

Mr. Ayer was a great admirer, as indeed all the board members were, of Miss Isom. Was their stand in large part a move to support her by backing her assistant? These were gentlemen with a sense of noblesse oblige. Was their stand in part a defense of a single woman who had no family or male friend to defend her? Those board members connected with financial establishments must have been hardest hit since their associates were the leaders in the bond drive。 
Amiong the members of the board, Rabbi Wise as a religious leader opposed to war, was experienced in defending this point of view. A man of great personal strength and influence, did he affect the thinking of his associates? A recent biographer of Rabbi Wise states that:

Insisting upon the right of anyone to his opinion, so long as it was not directed against public policy, Jonah persuaded his fellow directors that it was important not to lose sight of what was meant when it was said "We are fighting. to save the world for democracy."I

The veracity of this statement seems questionable when you add the sentence which follows it: "Accordingly, cool heads prevailed, and Miss Hunt kept her job."2 Is this rally fair to the other board members? Might not the pressures on them have been even greater than on a religious leader? These are questions to which we can place no certain answers. They were men of character. Few civic leaders in the United States in the spring of 1918 would have been willing to accept the censorship which such an unpopular stamd engendered. If the board members who upheld Miss Hunt are cast as heroes, it would be quite wrong to place Mr. Woodward in the role of villain. He reacted in the manner that a loyal citizen was expected to react and he believed his action to be right and proper. Mr. Woodward sincerely believed that the board stand was unpatriotic and not in the best interest either of the library or the community.

Critics; at least those reported by the papers, saw this fight in terms of absoliutes--one side was right, one side wrong. The most interest-

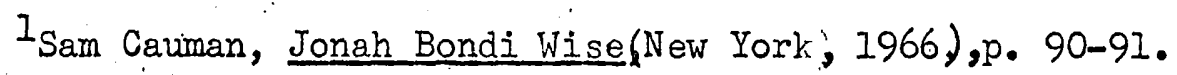
2 Ibid. 
ing criticism of the board's action in the Hunt case was printed in the

Oregon Voter for April 20. C. C. Chapman, the editor, presented a lengthy discussion of the pros and cons of the board action in "Niss Hunt's Case." 3 Mr. Chapman makes the point that the time had been reached when unreserved support of one's country should have been a condition of remaining in public employment, and public official and boards who did not appreaiate this fact failed to understand the temper of the people. It was just this failure which was responsible for the library crisis, Mr. Chapman felt. But when leading patriotic citizens of unquestionable loyalty called each other names and when their resignation from public office was demanded, it was high time, sald Mr. Chapman, to review the situation. $\mathrm{N}_{r}$. Chapman then makes this interesting comment.

How as sensible and patriotic men as the directors of the Library Board could have committed the grievous error of condoning Miss Hunt's perversity is a mystery. There is this to be said in extenuation of their attitude. Miss Hunt is an exceedingly capable woman. She is truly conscientious and was devoted to her duties as a servant of the public. She was giving her life to her career as a librarian, having sacrificed all that the average woman holds precious in order to fulfill her career. Miss Isom and her board knew that and were loathe to see Miss Hunt coerced into doing that to which her conscience objected. 4

Mr. Chapman suggests that the board should have reproved Miss Hunt formally for her perversity, and then suspended her for ninety days or. some such length of time, in order that she might reconsider her position. She would not, then, have been discharged peremptorily but have been given the chance to examine her principles once more. If she refused to conform, p. 10 . 3"Miss Hunt's Case," Oregon Voter, XLII, no. 3 (April 20, 1918), Ibid. 
then she should have been removed with the stigma of unfitness to hold public office. The board action in upholding Miss Hunt had the effect, in Mr. Chapman's opinion, of making her feel like a glorified martyr who was being upheld in her martyrdom. In accepting Miss Hunt's resignation, the board

Showed no courage in so doing. Rather, they showed a lamentable. lack of courage. Their action permitted Miss Hunt to carry alone the burden of their bungling. Upon her shoulders was unloaded that which the board did not have the courage to carry, the protection of the right of conscience. Miss Hunt remained true to what she thought was the best in her, while the board sought the first port in the storm. 5

Mr. Chapman concludes by commenting on the demands for resignation of $\mathrm{Mr}$. Ayer and the members of the board. "Their failure to rise to the opportunity they had to treat Miss Hunt justly while not condoning her perversity has subjected them to an avalanche of criticism that may for all time tend to discredit their public and patriotic activities."6. He finally echoes the pleas of the local newspapers, that this is no time for division but rather a time for all public servants to stand together. Mr. Chapman's solution, to give Miss Hunt a warning and time to reconsider, seems rather pointless since she must have been considering her position ever since the first Liberty Loan drive.

The ramifications of the Hunt case brought to the attention of Portland's citizens that, although they might demand the resignation of the library board, they were powerless to require it. In normal times both city and county were well content to leave the operation of the library in the capable hands of its distinguished governing body. The fact that the Asso-

5 Ibid.

6 Ibid. 
ciation still retained perogatives stemming from the old subscription library was of little concern as long as library service was excellent, although some people might have equated high standard of performance with freedom from political pressures:

Headlines in the Journal for April 14 reminded readers that "Library Board is not Subject to Public Control," adding that the board had entire supervision over the expenditure of the library funds contributed by the public. 'The library board was self-perpetuating and, as the administrative agent for a private corporation, it was not responsible to the people. The article went on to say that during the years it had spent building up one of the recognized great library systems of the country, the library board had established a traditionally independent policy which precluded referring issies of administration to the will of the public.

The criticism leveled by Board Member Woodward and by County Commissioner Holman against what they felt to be an artitrary decision to retain Miss Hunt was echoed, the Journal stated, by many Portlanders who asked, 'Who are the library: board members that they put themselves above public opinion?" The Journal reviewed both the history of the Library Association of Portland and the contractual arrangement between Multnomah County and the Association. The Hunt controversy, the paper pointed out, had caused the public to question if such a form of administration was truly democratic and whether it should be allowed to continue. Mr. Holman was quoted as saying, "There are too many push buttons between the library board and the public." 8

\footnotetext{
TThe Sunday Journal (Portland), April 14, 1918, p.I. ${ }^{8}$ Ibid.
} 
On cursory examination the library board did resemble an exclusive club whose limited membership was based on financial or professional standing. The board filled its own vacancles, which were infrequent, and most members served more than one term. What wás not apparent to the casual observer was the deep sense of service and obligation which membership on the board entailed. The responsibility for the book collection, for the buildings, for library service was a stewardship which each board member assumed. Perhaps it was this sense of continuity that set the library board apart from the ordinary elected or appointed civic body. Freedom from political pressure acted as a buffer between board and public, making It possible for this body to make an unpopular decision. Granted the distinguished membership of the board, it is doubtful if it would, or could, have sustained the minority point of view had it been composed of elected officials. Had it taken such a stand, quite probably the members would have been removed or voted out of office.

Public attention was soon diverted to other phases of war activity in Portland and the discontent over the board's action was forgotten. The board members rode out the storm and remained in office to serve the library for many years after the war was over. 
CHAPTER V

THE CASE OF THE CONSCIENTIOUS OBJECTOR AFFECTS

THE LIBRARY STAFF AND THE LIBRARIAN

The library staff evidently suffered from the fear of guilt by association. On Tuesday, April 16, 51 members of the staff of the Central Library, headed by janitor Samuel Nelson, voluntarily took the oath of allegiance to the United States government. The group appeared before County Judge Tazwell who administered the oath. The employees had previously contacted Richard W. Montague of the library board who. endorsed their action. An additional group, probably branch employees, also took the oath, bringing the tctal number to 79. This move, according to the Journal, anticipated action on the part of the Board of County Commissioners who had planned to have all county employees take an oath of allegiance. 1

The staff's reaction was a very normal one. For one thing, their jobs were threatened. Except for Miss Isom, Miss Hunt with her "large" salary, and perhaps a few others, library salaries were notoriously small and these workers couldn't afford any disruption in their pay checks. Moreover, they were reacting as average citizens to a suggestion of disloyalty. Neither Miss Hunt's action nor that of the library board was "normal" when measured against the prevailing temper of the time.

1The Daily Journal (Portland), April 17, 1918, p. 3. 
Their stand may also have been taken in defense of Miss Isom against the accusation of disloyalty on her staff, for she was a woman who comranded the respect and loyalty of her co-workers. Nowhere in the records is there any hint that Niss Hunt was given any support by her fellow librarians. She seems not to have been a very outgoing person. It would have taken a good deal of courage, but the staff might have prefaced their oath with a statement to the effect that, although they did not condone Miss Hunt for her actions, they did not belleve her to be a disloyal American!

When irresponsible members of the public demanded the resignation of Miss Isom, they touched off a chain reaction in support of Portland's head librarian. If few voices were raised in behalf of Miss Hunt, there were many who rallied in support of Miss Isom. She had the distinction of being the first librarian of the county library system. She had aided architect Albert Doyle in creating the gracious central library building, already a city landmark. A pioneer in library extension, she had brought books to the fringes of the county. Miss Isom was recognized as one of the nation's outstanding members of her profession. Portland was not a city to treat such a reputation lightly.

On April 21 the Journal reported that a strong testimonial to Miss Isom had been unanimously adopted at an unusually large meeting of the Professional Women's League. The statement adopted by the League read in part:

We have known as women the unobtrusive and unremitting qualities of Miss Isom's friendship, have enjoyed as workers the generosity of her cooperation, have participated as citizens in the benefits of the Portland library, so administered under her as to have become marked among the libraries of AmerIca for its service to the public. 2

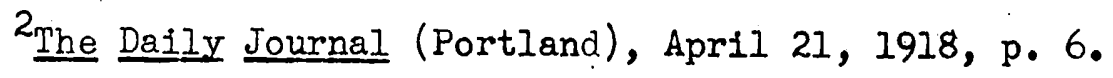


This article, and others, commented on the generous contributions which Miss Isom had made. Robert H. Strong, of the library board, was quoted by the Journal as testifying to the large sums of money contributed to the various war funds by Miss Isom, adding the interesting information that she had also adopted a French war orphan and had been contributing freely to Polish relief. ${ }^{3}$

C. C. Chapman, in the pages of the Oregon Voter, also reminded his readers of Miss Isom's generous contributions, adding that in size her subscriptions were surpassed by only a few people and they were people of great wealth. Mr. Chapman added: "She has been with us for seventeen years, has given us a library service that has been a blessing to our people, and her career is one Portland can be proud of even if she did make one mistake in judgement. 14

As for Miss Isom's war work, she anticipated the need for books in military installations. In June of 1917, when the American Library Association inaugurated plans for extension of library service to the armed forces, the headquarters of the Northwestern states was located in Portland with Miss Isom in charge of the whole operation. The library was headquarters for book drives and tons of books and periodicals were processed for shipment to camps and posts.

In a less spectacular way, all branches of the library served as agents for the sale of War Savings Stamps, for the distribution of war posters, and as meeting places for neighborhood groups engaged in war work. ${ }^{5}$

3The Daily Journal (Portland), April 21, 1918, p. 6. 1918), p. 27.

4"Stand By Miss Isom," Oregon Voter; XIII, No. 3, (April 20,

$5 \mathrm{~A}$ good sumary of the library's work is contained in the Iibrary Association of Portland, 55th Annual Report, Portland, 1918. 
To be referred to as disloyal must have hurt Miss Isom deeply for she was a sensitive woman. Judging by her large donations to the Red Cross, she may have felt that her personal contribution to her country's war effort was to provide comfort for the suffering and, as a librarian, to supply recreational material for the servicemen. If, in her heart she

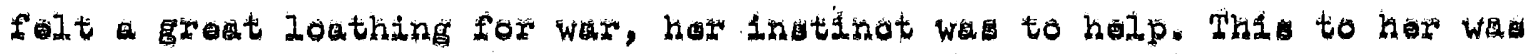
her duty and obligation just as surely as Miss Hunt felt hers to be a total withdrawal from such activity.

Whatever some Portlanders may have felt about her role in the Hunt affair, it did not affect her national reputation. She had the distinction of beingchosen by the American Library Association to organize hospital library service in France. She left Portland in the fall of 1918, on a six-month leave from the library. Miss Isom died of cancer in Portland in 1920 after a Iife of service. A bronze plaque placed on the wall of the second floor of the central library shows her, in relief, seated with a book in her hand, gazing out across the loblby. 
EPILOGUE

In Washington, when tho war ended; a tired President tried to convince the Congress that a league of peace-keeping nations would ensure the world against future wars. But the nation was tired of responsibilities. There was no well-defined plan for demobilization and the army was discharged with undue haste. War controls over industry were removed since the country expected private industry to switch back to a peacetime economy without restraints from the Federal government. Politics, largely adjourned during the war years, came to life again as a resurgent Republican party looked forward to a change in leadership. The necessity of wartime loyalty to the Administration no longer existed.

One of the first of the war agencies to disappear was the office of War Information, as Congress made haste to dispose of George Creel's powerful creation. It cut off his appropriations, terminated his functions, and provided no shelter for his records. For months the mass of files and papers his office had accumulated were shifted from place to place until they finally came to rest in an unused room in one of the government bureaus where they remained for years gathering dust.

Few people have been so intolerant of their fellow men as were Americans in the First World War. Even the coming of peace failed to end the trib-

\footnotetext{
1 Mark Sullivan, Our Times:Over Here, 1914-1918. (New York: Scribner, 1934), p. 455-6.
} 
ulations of those conscientious objectors who had been imprisoned, since there was no general policy of amnesty for the violators of the wartime Espionage Act. In spite of the work of various amnesty committees, five years passed before freedom was finaliy granted to all those who were convicted of having opposed war in 1917 and 1918.

Compared to their very real suffering, both in mind and in body, the Hunt case appears as a very small ripple in the larger wave of protest against war. Yet in one community, in Portland, Oregon, it served as a catalyst, forcing citizens to consider, if only briefly, the implications of such words as liberty and Ioyalty, and to choose whether a war being waged to make the world safe for democracy should also be waged against the democratic right to freedom of conscience. "In retrospect," Arthur Link has noted, "war hysteria seems the most frightful price the American people paid for participation in the First World War." ${ }^{3}$ Still, no recognizable civil liberties movement was developing in the country before 1917. It took years of war, mob violence, espionage laws, censorship, and hysteria to bring such a movement into being. Miss Hunt played out her small role in the battle for the defense of freedom of conscience. With the Armistice came a time for relaxation and forgetting as most Americans looked forward optimistically to resuming a pattern of normalcy. In Portland the principles of the Hunt case disappeared as figures of controversy. Mr. Woodward made peace with his associates on the library board. Despite Mr. Chapman's dire prediction, the board members

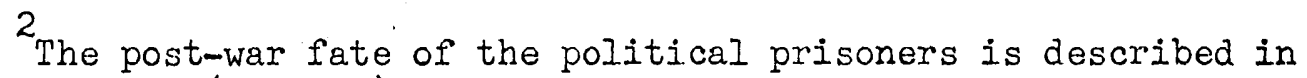
3 Arthur S. Link and William B. Catton, Amexican Epoch: A History of the United States Since the 1890's (New York: Knopf', 1963), p. 216.
} Peterson and Fite (op.cit.). 
remained in office, giving many years of public service to the library

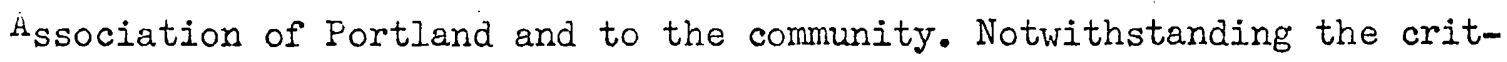
icism levelled against it in 1918, The Library Association contined to serve both city and county without any change in its structure. The board remained self-perpetuating.

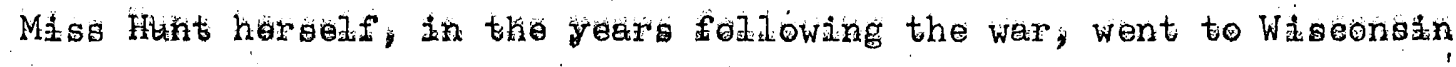
where she served as librarian of the Racine, Wisconsin, Public Library until her retirement in 1940. She died in Portland, Maine, in 1960 at the age of 85. Her obituary noted that "She was a member of the American Library Association and other literary societies. Soon after her retirement she returned to Portland [Maine] and made her home here. During her Iife she travelled extensivley in the United States and Mexico and visited most of the European nations several times. " Since there is no mention of any peace-oriented activity during the Second World War, her experience in Portland, Oregon, in 1918 may have been her last public defense of the right to conscientious objection.

Typewritten copy of the obituary of Miss M. Louise Hunt pubIished in the Portland [Maine] Press Herald, October 20, 1960. 


\section{BIBLIOGRAPHIC ESSAY}

All the protagonists in the Hunt case are dead. No members of the present library staff were employed by the library in 1918. The incident exists now only in the files of the local newspapers and in the archives of the Library Association of Portland. This report, therefore, has depended to a large extent on newspaper material.

\section{NEW SPAPERS}

Portland was most fortunate in 1918 in having three newspapers of superior quality. The leading paper then, as now, was the Oregonian founded in 1850. In the years prior to the First World War, the paper was Identified with the names of Henry L. Pittock and Harvey.W. Scott. Following the death of Scott in 1910, Edgar B. Pipes, as editor, continued the high standards set by his predecessors.

The Portland Evening Telegram was founded in 1877 by H. L. Pittock who was instrumental in the early development of the paper. Changes in management were frequent and by 1914 the paper had been sold to John E. and I. R. Wheeler. The Telegram filled the need for an afternoon paper in Portland. The paper was finally sold to California interests and merged with the Portland News in 1931. Details of this business deal were a subject of litigation for years. The Telegram had a long and honorable record although it was handicapped by its relation to the powerful Oregonian. John F. Carroll, long the editor, was a crusader with a deep sense of obligation to his public. 
The Portiand Jonetid, rouided in 1902, was long identipied with C.S. Jackson, athough he did not actualiy sound the paper. A newspaper man from Pendideton, he purchased the Journal and entered the fleld already occuplea by the Oregontit and the Telograrn. The paper's independent and

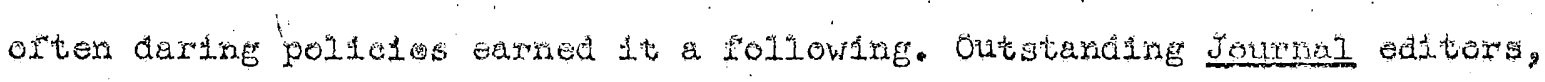
including George Trowbridge, B.F. Irvine, and Marshall N. Dana, helped establish the Journal as competition for the powerful Oregonian.

In their coverage of the Hint case, all three newspapers followed much the same pattexn. The actual incidents were reported in detafl and usually included lengthy statements from participants. Evon the editorials are sjmilar in tone. In the Funt affair, there was only one stand that a popular newspaper could takem that of the loyal Amerjcan putting love of country abote all eIse. AII three newspapers closed the Hunt reportage on the same dote -ain admonition to the reader to put controversy aside and strive for harmony in the community.

A short history of each of these newspapers can be found in George Tumbull, History of Oregon Newspapers, Portiand, 1939, p. 177, passim.

\section{REPORTS AND ARCHIVES}

The archives of the Library Association of Portland which were consulted for this report, consist of monthly reports prepared by the Librarian for the Iibrary Board, the minutes of the Board meetings, amd the Anmual Reports.

The Librarian's monthity report generally consisted of a summary of the pertinent events of interest to the governing board. The minutes of the Board theetings record the business transactions and general discussion; the Iibrartan traditionally sorves as Secretary to the Board. The 
Annual Report consisted of a report from the President of the Board, accounting for his stewardship; a report from the Treasurer; and a more lengthly report from the Librarian summarizing the year's activities of the various departments and services of the library.

The Annual Report is published. Copies may be found at such lib-

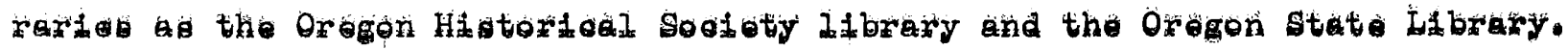
The board minutes and the Librarian's monthly report are treated as archival material and are housed in the Board Room of the library.

The library has also kept a scrapbook for a number of years. The librarian's secretary clips from the daily papers all articles pertaining to the library. These are pasted, in chronological order, on the blank pages of the scrapbook and constitute a history of newspaper coverage. Although reasonably complete, they do not, as this writer discovered, necessarily contain all newspaper accounts.

\section{BACKGROUND READING}

The problems raised by conscription and by the conscientious objector in the First World War were the subject of a number of serious studies written within a few years of that conflict. Because they tried to examine the problems objectively, they still have much to say that is pertinent today.

Norman Thomas, The Conscientious Objector in America, New York, 1922, discusses the different types of objectors and the motives which activated them. He is sympathetic and fair-minded in portraying the persecutions and cruelties which the passage of the Selective Service Act of 1917 perpetrated. Mr. Thomas manages to maintain an objective point of view. Clarence Marsh Case, Non-violent Coercion: A Study in Methods 
of Soc1al Pressure, New York, 1923, presents a study of non-resistance, considered from its historical, ethical, and social implications. Zechariah Chaffee, Jr. in Freedom of Speech in the United States, New York, 1920, covers this subject from the point of view of one well acquainted with law, discussing the principles and implications of the First amendment. Since freedom of speech is an ever-occurring and unresolved problem, Mr. Chaffee revised his book with the outbreak of the Second World War, Free Speech in the United States, Cambridge, Mass., 1941. Mark Sullivan treats the problems of the war years in a somewhat lighter vein in volume 5 of our Times: Over Here, 1914-1918, New York, 1934. Two college professors, Harold J. Tobin and Percy Bidwell, in Mobilizing Civilian America, New York, 1940, a study done for the Council on Foreign Relations, include an interesting chapter on propaganda and censorship. They review the machinery set in motion in 1917-18 to orystalize public opinion and express the hope that censorship action will be better organized in the future.

In more recent years there has been a revival of interest in the concept of conscientious objection. Horace C. Peterson and Gilbert C'. Fite, in Opponents of War 1917-18, Madison, Wisconsin, 1957, attempt to show what individuals or groups opposed the war, why they acted as they did, and what happened to them. Their adversaries, and what they did to their victims, came in for a good deal of attack in the book. The authors conclude that this type of thinking is still all too prevalent approximately forty years later. A very recent study is Donald Johnson's, The Challenge to Freedom: World War I and the Rise of the American Civil Liberties Union, Lexington, Kentucky, 1963. This is the story of the emergence of the Civil Liberties Union in the five-year period of Ultra- 
American hysteria which followed World War One. It is also a review of the work of Roger Baldwin, founder of the ACLU, and his struggles during the war years over exemption for conscientious objection and punishment for violation of the espionage laws.

\section{BIOGRAPHY}

Brief sketches of the older members of the Library Board may be located through such standard sources as Joseph Gaston, Portland, Its History and Builders, Chicago, 1911. A contemporary Portland City Directory was used to verify occupations. The only Board member to receive more than local notice was Rabbi Wise in Sam Cauman, Jonah Bondi Wise, New York, 1966. This is a highly sympathetic but uncritical biography of one of this country's great rabbis. The brief section on Portland containg inaccuracies. Mr. Cauman is probably more familiar with Rabbi Wise's years in New York City. An interesting, brief commentary on Rabbi Wise's relations with his congregation during the war years will be found in a history of Congregation Beth Israel, by Rabbi Julius J. Nodel, The Ties Between: A Century of Judaism on America's Last Frontier, Portland, 1959.

\section{PERIODICALS}

A check of the files of the Oregon Historical Society failed to locate any periodicals published in Portland during the war years with the exception of the Oregon Voter. This independent weekly was edited by C. C. Chapman and gave information on political campaigns and candidates as well as news of financial, institutions. The opinions, often caustic, were strictly those of Mr. Chapman. 
The biographical sketch of Miss Isom, written by Bernard Van Horne, a former Iibrarian of the Library Association of Portland, has been cited in the body of this report. It touches briefly on the Hunt case and is of particular value in sumarizing the career and personal ife of Miss Isom. "Mary Frances Isom: Creative Pioneer in Library Work in the Northwot," Widon Libracy Bulietin (Fobruary, 1959). Thio artiole wa reprinted as a chapter in American History Reader, New York, 1961. 